\title{
QUANDO “SER PROFESSOR" SERVIA ÀS ELITES: A ESCOLA NORMAL IGNÁCIO AZEVEDO DO AMARAL (1950-1970)
}

\author{
Fábio Souza Lima (Universidade Federal do Amazonas)* \\ https://orcid.org/0000-0002-1855-1738
}

\section{RESUMO}

Este artigo tem por objetivo abordar o tema da formação de professores como interesse das elites cariocas, tomando por base a história da instalação da Escola Normal Ignácio Azevedo do Amaral, no bairro da Lagoa, Zona Sul, entre os anos de 1950 e 1970. Trata-se de uma análise com base nos periódicos 0 Cruzeiro e Diário Carioca, aliada ao estudo de uma bibliografia específica que aborda o jogo político que envolveu a criação de uma unidade para o atendimento exclusivo das moradoras da região mais rica da cidade. Na esteira do que escreveram Louro (1997) e Werebe (1968) sobre serventia do ensino normal para as mulheres de classes sociais mais altas, concluímos que a depreciação salarial, a perda de status e a queda do privilégio de acesso automático ao serviço público afastaram os grupos sociais citados da profissão docente.

Palavras-chave: História da educação. Formação de professores. Escola Normal Ignácio Azevedo do Amaral.

\section{ABSTRACT \\ WHEN “TEACHER" SERVED ELITES: THE IGNÁCIO AZEVEDO DO AMARAL QUALIFICATION SCHOOL (1950-1970)}

This article aims to address the theme of teacher education as an interest of the carioca elites, based on the history of the establishment of the Ignácio Azevedo do Amaral Qualification School, in the Lagoa district, South Zone, between 1950 and 1970. It is based on an analysis based on the journals 0 Cruzeiro and Diário Carioca, allied to the study of a specific bibliography that deals with the political game that involved the creation of a unit for the exclusive care of the residents of the richest region of the city. In the wake of what Louro (1997) and Werebe (1968) wrote about the usefulness of normal education for women of higher social classes, we conclude that wage depreciation, loss of status and the fall of the privilege of automatic access to public service, removed the mentioned social groups from the teaching profession.

Keywords: History of education. Teacher training. Ignácio Azevedo do Amaral Normal School.

Doutor em Educação pela Universidade Federal do Rio de Janeiro (UFRJ). Professor de História da Educação na Faculdade de Educação da Universidade Federal do Amazonas (FACED/UFAM). E-mail: fabiosouzaclima@gmail.com 


\section{RESUMEN}

\section{CUANDO EL “MAESTR0" SIRVE ELITE: LA ESCUELA NORMAL IGNÁCIO AZEVEDO DO AMARAL (1950-1970)}

Este artículo tiene como objetivo abordar el tema de la formación docente como un interés de las élites cariocas, basado en la historia del establecimiento de la Escuela Normal Ignácio Azevedo do Amaral, en el distrito de Lagoa, Zona Sur, entre 1950 y 1970 . Se basa en un análisis basado en las revistas 0 Cruzeiro y Diário Carioca, aliadas al estudio de una bibliografía específica que trata sobre el juego político que involucró la creación de una unidad para el cuidado exclusivo de los residentes de la región más rica de la ciudad. A raíz de lo que Louro (1997) y Werebe (1968) escribieron sobre la utilidad de la educación normal para las mujeres de clase alta, concluimos que la depreciación salarial, la pérdida de estatus y la caída del privilegio del acceso automático al servicio público, eliminó los grupos sociales mencionados de la profesión docente.

Palabras clave: Historia de la educación. Formación de profesores. Ignácio Azevedo do Amaral Escuela Normal.

\section{Introdução}

A capital brasileira do final dos anos 1950 ainda mantinha um ritmo de crescimento populacional considerável desde os anos 1920. Cinquenta por cento das pessoas que viviam no Estado do Rio de Janeiro escolhiam estar mais próximas do centro de poder brasileiro, isto é, o Distrito Federal (INSTITUTO BRASILEIRO DE GEOGRAFIA E ESTATÍSTICA, 2019). Paralelamente, o desenvolvimento do aparelho educacional no Brasil apresentava um crescimento que pode ser ilustrado pelo índice de analfabetismo de jovens com até 15 anos, que passou de $50,6 \%$ em 1950 para $39,7 \%$ em 1960 (PINTO; BRANT; SAMPAIO, 2000). Tratava-se da realização do que o historiador Rui Canário (2008) assinalou como "Os trinta gloriosos" (1945-1975) anos em que os países do ocidente experimentaram uma explosão na procura das famílias por bancos escolares para seus filhos.

Mesmo com esse avanço, o corpo de professores do sistema de ensino da capital brasileira era sustentado apenas por um curso de formação de professores normalistas, a antiga Escola Normal da Corte, transformada em Escola Normal do Distrito Federal por ocasião da criação da República e, mais tarde, em 1932, elevada à condição de Instituto de Educação (IE). Por conta dessa exclusividade, concentrada apenas na região do Centro da cidade, frequentemente os alunos do terceiro ano dessa unidade eram convocados para trabalhar como professores na rede de ensino na tentativa de cobrir as necessidades do sistema (LOPES, 2013). Essa estrutura de apenas um curso de formação de professores normalistas foi mantida até 1946, com a criação, sob muitos protestos e resistências, da Escola Normal Carmela Dutra (ENCD), no subúrbio da cidade (LIMA, 2017).

Tal Curso seguia o critério de formação de alto padrão em que os filhos das elites, embora estudantes de uma unidade pública, frequentemente eram retratados como alunos de uma espécie de "clube". Em variados artigos encontrados na revista 0 Cruzeiro, era possível encontrar narrativas e imagens em que a vida social das jovens normalistas parecia ter mais importância do que os estudos. Na edição de 22 de outubro de 1959, em meio a um conjunto de cerca de 40 imagens veiculadas entre as páginas 13 e 20, era possível encontrar referências às alunas como "rainha da primavera", "24 horas com as garotas mais bonitas da cidade", "quando 
elas passam, uniformizadas, pelas ruas do Rio, chamam as atenções de centenas de admiradores de todas as idades", "garota cinematograficamente magnética", "bonita e educada,' "fica bem em qualquer fotografia", "brotinho em flor", "Normalista Linda", "sereias com maiô negro", "Juventude e Beleza", “[...] É uma família de normalística do Rio. Família esplêndida", entre outras (FUNDAÇÃO BIBLIOTECA NACIONAL, 2019a).

Figura 1 - Imagens da reportagem "As normalistas do Rio de Janeiro - vestida de azul e branco", da revista O Cruzeiro de 22 de outubro de 19591949

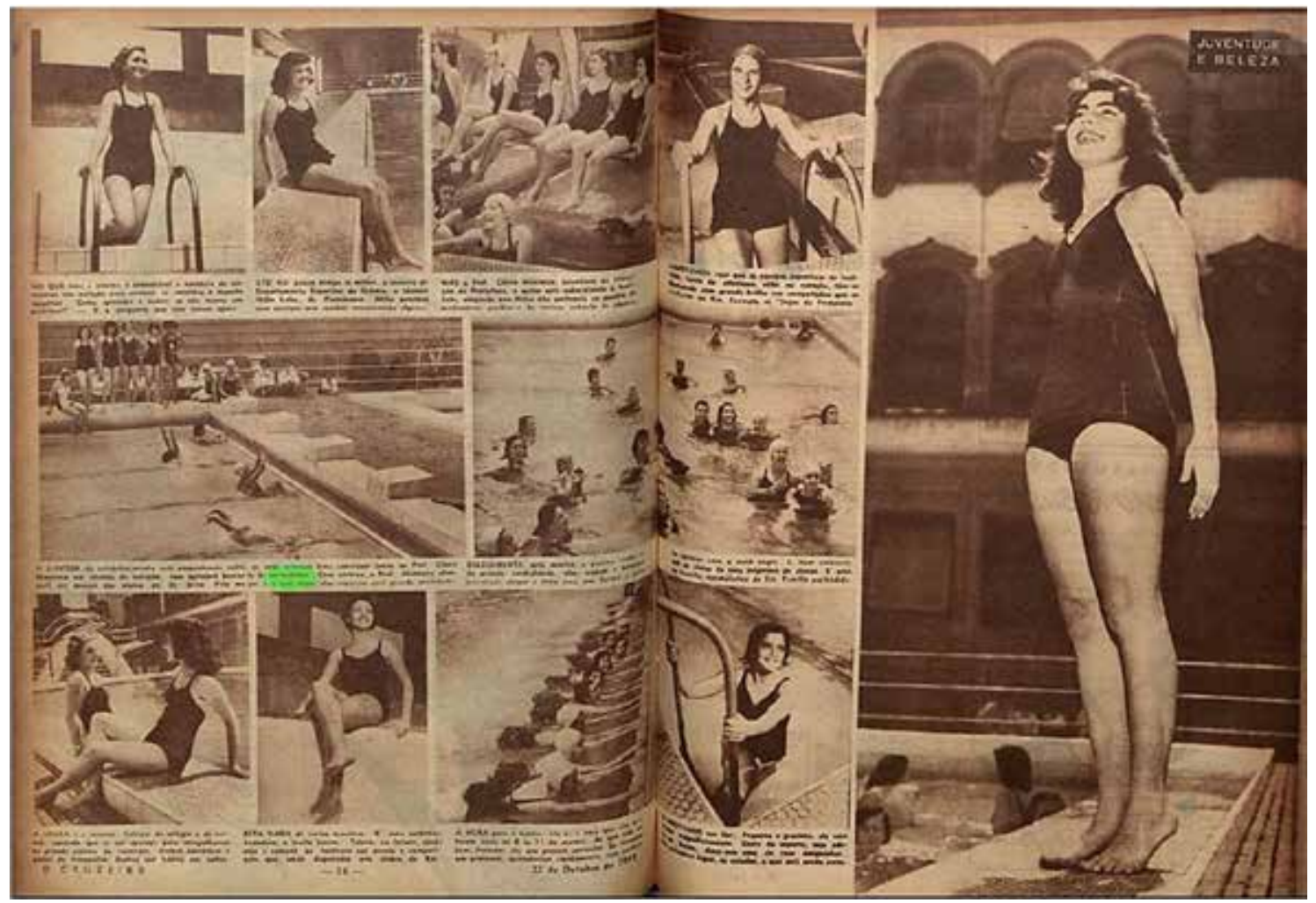

Fonte: Fundação Biblioteca Nacional (2019a).

A matéria, no entanto, não terminava na vigésima página, mas sim depois das propagandas, na vigésima quarta. Para entender esse procedimento da revista, torna-se importante conhecer um pouco mais sobre esta e destacar algumas ressalvas, próprias de uma análise historiográfica. Em uma análise de periódico, conforme apontou o historiador Antonie Proust (1998 apud LUCA, 2005), importa menos pelo que ele diz, e mais pela maneira como ele diz, os termos que ele utiliza, os campos semânticos que ele segue. A leitura de 0 Cruzeiro, portanto, necessitou algum conhecimento do seu funcionamento, conhecimento do público que atendia e das suas finalidades da distribuição de seus exemplares.

A revista 0 Cruzeiro surgiu em 1928, idealizada pelo jornalista português Carlos Malheiro
Dias, mas de propriedade de Assis Chateaubriand, sendo editada no Rio de Janeiro. Na década de 1940, o periódico passou de uma tiragem de 48 mil para 370 mil exemplares por semana, chegando a alcançar 720 mil ao retratar o período da morte de Getúlio Vargas, em meados dos anos 1950. Nesse período, a revista chegou a manter sucursais em Tóquio, Nova Iorque, Roma, Lisboa, Londres e Paris, circulando também em vários países latino-americanos, além dos Estados Unidos (BRASIL, 2015).

Fazendo o gênero de revista de variedades, o semanário de Chateaubriand focava de tudo um pouco: tratava de assuntos políticos, sociais e econômicos, sem deixar de lado efemérides e assuntos de vulto na semana, esportes, moda e celebridades, humor ilustrado, noticiário inter- 
nacional, história, concursos e promoções, colunismo social, arte e cultura - além da publicação de contos e poemas. (BRASIL, 2015).

Na reportagem em questão, interrompida a sequência de imagens por algumas propagandas, quatro páginas depois, em um pequeno trecho era possível ler o destaque que fugia ao padrão da unidade: "críticas de uma normalista côr de jambo”. Um parágrafo em que eram destacadas algumas palavras de uma aluna "cor de jambo" do IE, que não apareceu nas fotos, versava sobre falta de elevadores na unidade que tinha apenas três andares (FUNDAÇÃO BIBLIOTECA NACIONAL, 2019a). Apesar da importante discussão possível sobre discriminação e acesso ao ensino pelos negros no Brasil, pretendemos apenas contribuir para essa questão abordando a frugalidade das questões presentes na reportagem. Para entender, portanto, por que a revista deu tanto destaque a assuntos relativamente frugais, é importante triangular as informações desse periódico com a literatura especializada sobre o papel da mulher nesse período histórico. A pedagoga - e também normalista - Maria José Garcia Werebe (1968, p. 213) explicou a procura pelo Curso Normal da seguinte maneira:

[...] salientam-se as incontestáveis vantagens que o ensino normal oferece. De fato, além de ser, pela constituição do seu currículo, apropriado para a formação de futuras 'esposas e mães', confere um diploma profissional que, numa eventualidade, pode ser útil, funcionando como 'seguro de vida'.

Seguindo esse pensamento, a historiadora Guacira Lopes Louro (1997, p. 471), ao escrever Mulheres na sala de aula, também apontou que essa seria "a meta mais alta dos estudos a que uma jovem poderia pretender". Essa "boa preparação" poderia ser ainda alinhada à tradicional imagem do casamento "perfeito" da normalista, a ser realizado preferencialmente com um cadete recém-formado na Escola Militar, o que garantiria um bom status e segurança ao restante de sua vida.

Contudo, vale ressaltar, a citação de Werebe (1968) introduz outra questão quando aponta o diploma de professora como um "seguro de vida", pois pode estar se referindo a um privilégio que as alunas normalistas mantiveram durante quase oitenta anos e que pode oferecer outra perspectiva de interpretação sobre a procura e o prestígio mantido pelas Escolas Normais nessa época. No decorrer deste artigo, portanto, desenvolveremos melhor a relação entre esse privilégio e a construção da Escola Normal Ignácio Azevedo do Amaral, erigida na região mais rica da cidade, para atender exclusivamente as jovens da região.

Para concluir esta introdução, também é importante salientar que nesse contexto de necessidade de quebra de exclusividade na formação de professores normalistas no Distrito Federal (DF) e de resistências quanto à extensão de privilégios a outras regiões da capital, foi promulgada a Lei no 906, de 16 de dezembro de 1957, que criava uma unidade escolar e ainda previa a construção de mais duas unidades de Escolas Normais, uma na Zona Norte, outra na Zona Sul da cidade. Dois anos depois, chancelada por pareceres assinados por Lourenço Filho e Anísio Teixeira que previam a inauguração de quatro Escolas Normais para o bom atendimento da cidade (FUNDAÇÃO BIBLIOTECA NACIONAL, 2019b), a Secretaria de Educação, em um jogo político que envolvia os interesses de parlamentares, jornais e revistas da época, triplicou a quantidade de unidades inauguradas entre 1959 e 1960 (LIMA, 2016).

\section{um "seguro de vida"}

Na primeira década do século XX, em meio a um processo de constituição do afamado uniforme das normalistas, as palavras do jurista e então Senador da República Ruy Barbosa ilustravam o prestígio do qual deveria ser cercada a profissão (LIMA, 2018). A importância da profissão, historicamente negligenciada pelos governos de diferentes esferas, agora espelhava a concepção de que seria por meio da educação que a nação brasileira alcançaria a "modernização" e "civilidade", o que também 
lhe conferia status na construção dessa nova sociedade.

[...] à futura professora, aqui tenho o que, em um bello relatório, escreveu o eminente Senador da República, Dr. Ruy Barbosa (lê): 'Estabelecer os melhores methodos, prover o mais completo material clássico a todas as escolas, rodear 0 magistério das mais altas vantagens sociaes, tudo será improfícuo e vão se não organizarmos a educação do mestre.' (LEITE RIBEIRO, 1914, p. 7).

Aquilo que se mostraria mais tarde como uma das "mais altas vantagens" a que se refere Ruy Barbosa já fazia parte da formação de professores desde o Império, pois ao descrever a criação e implementação da Escola Normal na capital brasileira do século XIX, Sonia Lopes (2012) observou que já existia no seio do Império a ideia de "civilizar" o povo da capital. Decorrente dessa ideia, transformar a carreira do magistério em uma ocupação um pouco mais atraente já ocupava as políticas públicas antes mesmo da República. Nesse contexto, foi desenvolvido um procedimento que garantiu o acesso automático de professores ao serviço público. Assim, nos artigos 22 a 24, o Decreto 1.331-A, de 17 de fevereiro de 1854, versava sobre a nomeação de docentes da seguinte maneira:

Art. 22. A nomeação dos professores publicos será feita por Decreto Imperial.

Art. 23. Em igualdade de circumstancias preferirão para o provimento nas escolas:

$\S 1$ 을 0 professores das do primeiro gráo para as do segundo, tendo leccionado com distincção por três annos.

$\S 2^{\circ}$ Os professores adjuntos que ainda não estiverem nas circumstancias do Art. 39 [exames de finais realizados pelo Inspetor Geral], mas houverem praticado satisfactoriamente por três annos.

$\S 3$ 응 Os professores particulares que por mais de 5 annos tenhão exercido o magisterio com reconhecida vantagem do ensino.

$\S 4^{\mathrm{o}}$ Os Bachareis em letras, e os graduados em qualquer ramo da instrucção superior do Imperio.
Art. 24. 0 provimento em qualquer cadeira, guardadas as regras precedentes, será considerado vitalicio, depois de 5 annos de effectivo serviço. (BRASIL, 1854).

Embora o parágrafo quarto do artigo 23 acenasse para a contratação de profissionais com a titulação superior em qualquer área de instrução, devemos destacar que grande parte desses novos servidores públicos não tinha a formação adequada para atuar em sala de aula. Nesses casos, como podemos depreender dos demais parágrafos do mesmo artigo, os professores eram pessoas de notório saber que haviam sido escolhidos para assumir os cargos do magistério nas comarcas em que residiam por toda a vida.

A fim de mudar essa situação, ainda segundo Lopes (2012), o artigo 19 do novo Regulamento de Ensino publicado em 18 de janeiro de 1877 afirmava que os professores adjuntos efetivos ou interinos deveriam, obrigatoriamente, cursar a Escola Normal da Corte para permanecer no exercício do magistério primário. Aqueles que não o fizessem, ou que ficassem reprovados nos exames por duas vezes, poderiam ser destituídos de suas funções de servidores públicos. Para essa autora, essa ação do governo aumentou a demanda pela Escola Normal pública. A sua avaliação era que ser professora ou se manter como professora no Município da Corte, apesar de agora estar condicionada a uma formação longa e sistemática, passava a ser interessante porque seus custos funcionavam às expensas do Estado e o seu emprego, garantido por Lei, assegurava um salário vitalício. Ainda assim, mesmo com essa formação institucionalizada, professores continuavam sendo formados "pela prática", isto é, iniciavam a carreira como auxiliares dos professores efetivos e a partir desse contato com a prática docente tornavam-se adjuntos interinos, chegando ao serviço público vitalício por meio do parágrafo $3^{\circ}$ da Lei de $1854 .^{1}$

Em 1888, por fim, com o Decreto no 10.060 ,

1 Sobre esse tipo de formação, ver os trabalhos de Heloisa de Oliveira Villela, em especial Villela (1990). 
de 13 de outubro, o Império determinou a necessidade da passagem desse profissional pela Escola Normal da Corte:

Art. 166. Receberá o título de habilitação para professor ou professora das escolas públicas e instrução primária do município da Corte o alumno-professor que obtiver aprovação no exame de que trata o art. 142 [aptidão pedagógica].

Os títulos de habilitação serão passados conforme o modelo anexo ao presente Regulamento.

Art. 167. Esses títulos darão às pessoas habilitadas pela Escola [Normal da Corte] o direito de serem exclusivamente providas, independentemente de concurso, nas cadeiras púbicas de instrução primária do município da Corte do $1^{\circ}$ ou do $2^{\circ}$ grau, e nos respectivos logares de professores adjuntos. (BRASIL, 1888).

Tornava-se, assim, obrigatória a passagem pela Escola Normal para os postulantes à carreira do magistério público primário. 0 regulamento de 1888 ainda trazia, em anexo, o modelo de requisição do título, com o qual o professor aprovado no exame pedagógico do último ano de formação estaria habilitado a exercer o magistério nas escolas públicas de instrução primária do Município da Corte.

0 "seguro de vida" ao qual se referiu Werebe (1968), usado caso falhasse o plano de casamento imediatamente após a formação, era, portanto, o diploma de professora normalista. Mais do que isso, com a formação profissional, a normalista garantia relativa independência e, em uma possível falta do marido, um salário para o atendimento da família até o fim da vida. 0 funcionamento desse privilégio oferecido aos professores da Escola Normal da Corte se manteve mesmo após o fim do Império, atualizando-se na Escola Normal do Distrito Federal e, posteriormente, no Instituto de Educação e, mais tarde, chegando às demais unidades de formação de professores da cidade. Consequentemente, a boa preparação para os papéis de esposa, mãe e professora, o status social como fruto de uma sociedade que buscava a modernização pela educação, além da segurança financeira, tornaram os concursos para
Curso Normal das escolas públicas altamente concorridos.

\section{A campanha: 0 sofrimento das elites}

Alinhado ao crescimento populacional, estava a necessidade pela formação de mais professores, um parecer assinado por Lourenço Filho e Anísio Teixeira (FUNDAÇÃO BIBLIOTECA NACIONAL, 2019b) que atestava a necessidade de construção de mais unidades de Escolas Normais na cidade, além dos interesses das famílias que preparavam suas filhas em cursinhos pré-normais esperando, se não um crescimento social, uma maior segurança para o futuro delas. Grupos de educadores ligados à perspectiva de manutenção da centralização do ensino chegaram a se manifestar contrariamente à criação de novas unidades. Entre esses grupos, os diretores do Instituto de Educação e da Escola Normal Carmela Dutra ${ }^{2}$ chegaram a se manifestar radicalmente contrários à criação de novas unidades (FUNDAÇÃO BIBLIOTECA NACIONAL, 2019c).

Diante da resistência de grupos ligados ao IE e à ENCD, uma ação astuciosa do vereador Miécimo da Silva (Partido Social Progressista - PSP), aliado ao vereador Frederico Trotta (Partido Social Democrático - PSD), que por sua vez encabeçou o projeto, garantiu a aprovação de uma Lei para criação de mais três unidades. Miécimo incluiu no projeto de Lei, cujo caput era "Determina a distribuição de lotes gratuitos aos favelados, soluciona o problema das favelas, e dá outras providências" (DISTRITO FEDERAL, 1957), artigos que criavam uma Escola Normal na região de sua base eleitoral, o bairro de Campo Grande. No mesmo projeto, camuflados no meio de outros artigos sobre a distribuição de terras a favelados, a proposta de criação de duas Escolas

2 A ENCD ficou submetida administrativamente e pedagogicamente ao IE até 1953, funcionado como uma espécie de posto avançado no bairro de Madureira, que à época, era relacionada no zoneamento da cidade como zona suburbana remota e de difícil acesso (LIMA, 2016). 
Normais, uma na Zona Sul, região mais rica da cidade, onde estavam os bairros da Lagoa, Botafogo, Flamengo, Leme, Leblon, Copacabana, São Conrado, Ipanema, Gávea, Humaitá, Laranjeiras, entre outros, e a outra unidade a ser construída na Zona da Leopoldina, que na época cobria vários bairros suburbanos do Norte, do Caju (região portuária) até o Cachambi. Depois de uma negociação com outros parlamentares que buscavam votos para uma obra no Maracanã, o Projeto no 32 , de 1952, da Comissão de Economia e Finanças, tornou-se a Lei no 906, de 26 de dezembro de 1957 (LIMA, 2017).

\section{LEI N. 906 - DE 16 DE DEZEMBRO DE 1957}

Determina a distribuição de lotes gratuitos aos favelados, soluciona o problema das favelas, e dá outras providências.

\section{[...]}

Art. 15. Ficam igualmente criadas mais duas Escolas Normais, sendo uma na zona sul e outra na zona suburbana da Leopoldina. Devendo ser enquadradas como suas congêneres, nas bases da Lei Orgânica do Ensino Normal, com a direção subordinada à Secretaria Geral de Educação e Cultura, obedecendo ao mesmo regime. (FUNDAÇÃO BIBLIOTECA NACIONAL, 2019d).

Embora Miécimo, conhecido como o vereador das bicas d'água, desde então estivesse a colher os frutos da Lei no 906 em sua base eleitoral, tornando-se deputado estadual da primeira legislatura do recém-criado Estado da Guanabara (1960-1975), Frederico Trotta, por outro lado, demoraria mais para inaugurar a Escola Normal da Zona Sul.

Num período histórico em que a busca por cadeiras escolares ganhava força, a retórica política de criação de escolas era forte. Nesse sentido, a atuação de Trotta foi respaldada por uma verdadeira cruzada realizada pelo jornal Diário Carioca, que iniciou uma campanha com uma série de reportagens sobre a necessidade de uma Escola Normal na Zona Sul do Rio de Janeiro. As manchetes da nova unidade, presentes nas primeiras páginas do periódico, envolveram representantes de associações de bairros da zona sul, além de nomes da educa- ção com algum prestígio e outros políticos que quisessem entrar no movimento. Entretanto, o jornal não deixou de destacar o vereador Frederico Trotta (PSD) como líder do movimento. Em troca, nesse jogo político, Trotta conseguiu que a Câmara dos Vereadores concedesse ao jornal Diário Carioca o título de benemérito da cidade do Rio de Janeiro na figura do seu presidente-diretor Horácio de Carvalho Júnior (RÉMOND, 2003).

0 vereador Frederico Trotta não aparecera no estratagema político de Miécimo da Silva para a criação da Escola Normal de Campo Grande (além dos vagos artigos que criavam outras unidades) por acaso. Trotta, que tinha um passado militar, como Major - e, posteriormente, Coronel - do Exército, havia sido escolhido pelo presidente Eurico Gaspar Dutra para ser o governador do Território Federal do Iguaçu durante o ano de 1946, e, depois, governador do Território Federal do Guaporé entre os anos de 1947 e 1948. ${ }^{3}$ Com um programa de governo que, em parte, focava na educação, na saúde e nas comunicações, Frederico Trotta criou o primeiro Curso Normal Regional, sendo homenageado pela primeira turma da unidade (SILVEIRA, 2008).

Além de militar e político, Trotta havia se formado em Direito e foi certificado a dar aulas de história, português e matemática (TROTTA, 2017). Também foi poeta e jornalista, trabalhando em vários periódicos, como 0 Jornal, Manhã, A Tarde e Diário do Povo (WEST, 2011). Havia neste personagem histórico para as Escolas Normais, portanto, um passado que relacionava ensino, política e mídia em sua trajetória, algo essencial para compreendermos o desenvolvimento do jogo político que envolveu esse modelo educacional (RÉMOND, 2003).

O Diário Carioca, por sua vez, havia sido

3 0 Território Federal do Guaporé foi criado pelo Decreto-Lei lei n.o 5.812, de 13 de setembro de 1943, através da Lei Ordinária no 2731, de 17 de fevereiro de 1956 transformouse em Território Federal da Rondônia e posteriormente em Estado. Frederico Trotta foi o seu último governador (PRIORI et al., 2012). 
fundado em 1928, por José Eduardo Macedo Soares, entretanto, passara às mãos de Horácio de Carvalho Júnior, em 1932. Neste período, segundo Carlos Eduardo Leal, ao escrever verbetes para o Centro de Pesquisas e Documentação de História Contemporânea do Brasil (CPDOC), "Tudo que interessava à elite econômica do país em geral era encampado pelo jornal de Macedo Soares, decorrendo daí sua posição fluida e imprecisa" (FUNDAÇÃO GETÚLIO VARGAS, 2017a). Benício Medeiros (2011), na série Cadernos da Biblioteca Nacional, aponta que os esforços dos proprietários tinham a intenção de transformá-lo em um periódico nacional, o que quase aconteceu, pois na década de 1950 ele chegou a ser publicado com 72 páginas. Segundo esse autor, "o DC era um jornal de elite, de poucos leitores, relativamente, mas de enorme influência [...]" (MEDEIROS, 2011, p. 10).

Dessa maneira, como aponta a historiadora Tânia Regina de Luca (2006), a imprensa não é simplesmente mais um simples receptáculo de informações e textos, mas também um objeto de investigação. Nesse sentido, conhecer melhor as origens e interesses desse periódico é necessário para utilizá-lo com a criticidade necessária (LUCA, 2005).

A aproximação de Trotta e do Jornal Diário Carioca cumpria o interesse de ambos em atender as suas bases e aumentar a circulação de seus nomes. 0 meio para que isso acontecesse foi a adoção do interesse das famílias da Zona Sul do Distrito Federal como bandeira política. Assim sendo, o Diário Carioca iniciou o movimento com uma pergunta retórica: "Por que a Zona Sul tem de ser sacrificada?" (FUNDAÇÃO BIBLIOTECA NACIONAL, 2019e), enquanto mostrava Frederico Trotta a aplaudir sua própria campanha.

Temos na Praia Vermelha o terreno da Escola Primária Minas Gerais, local aprazível e de fácil acesso durante o dia. Também poderiam se aproveitados os terrenos que a Prefeitura possui na Gávea. 0 melhor, porém, seria o grande terreno na Praça do Lido, que além de ser em zona central, pode ser facilmente alcançado pelos moradores do Flamengo, Botafogo,
Gávea, Jardim Botânico, Ipanema e Leblon, além de atender o bairro mais populoso dessa capital, Copacabana. [...] É um erro supor que Copacabana e os bairros da Zona Sul não tem direito ao ensino gratuito. É preciso olhar para eles e ver que ali mora uma maioria de pais de famílias de nível médio e mesmo pobre. (FUNDAÇÃO BIBLIOTECA NACIONAL, 2019e).

Figura 2 - Foto da reportagem "População da Zona Sul pede Escola Normal”, do Diário Carioca de 20 de abril de 1959

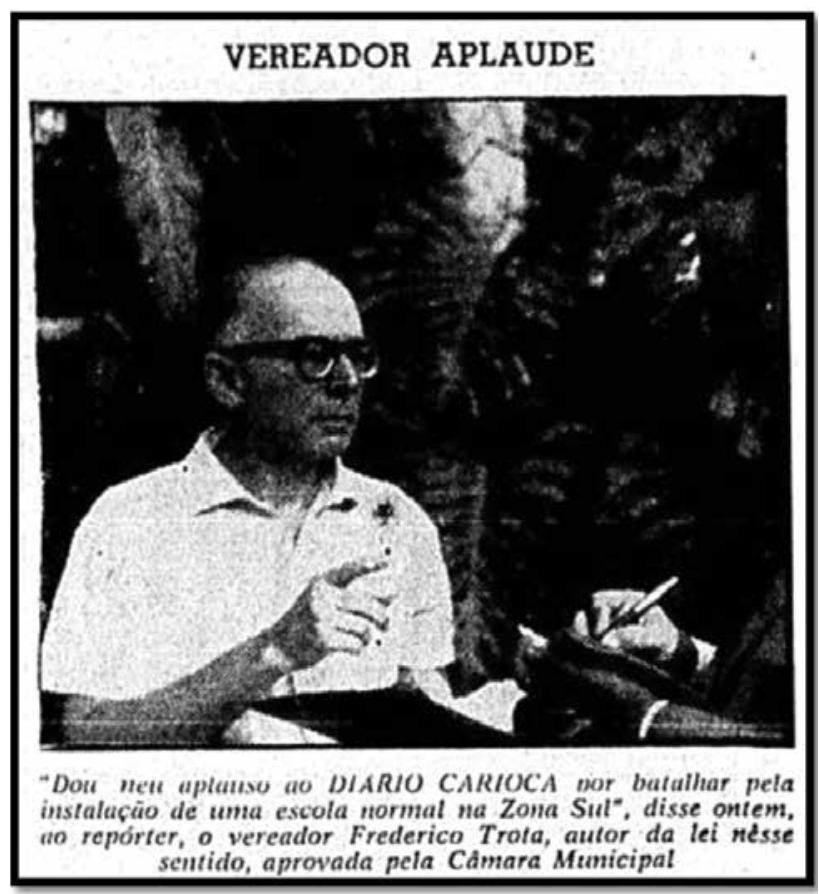

Fonte: Fundação Biblioteca Nacional (2019e).

Para atender aos interesses dos moradores da Zona Sul carioca - onde, segundo o Diário Carioca, também viviam as classes médias e os pobres -, o periódico desenvolveu uma série de reportagens em 1959 buscando mobilizar diferentes setores sociais. Em sequência, todos na primeira página, era possível ler manchetes como: "Literatos a favor da Escola Normal na ZS.” (FUNDAÇÃO BIBLIOTECA NACIONAL, 2019f); "Leblon e Lagoa pedem Escola Normal na ZS." (FUNDAÇÃO BIBLIOTECA NACIONAL, 2019g); "Urca vai lutar por Escola Normal." (FUNDAÇÃO BIBLIOTECA NACIONAL, 2019h); "Escola Normal pode ser instalada logo." (FUNDAÇÃO BIBLIOTECA NACIONAL, 2019i); "Moças de Copa apoiam Escola Normal na ZS." (FUNDAÇÃO BIBLIOTECA NACIONAL, 2019j); “Gávea Aplaude [...] SACI [Sociedade dos Amigos de Copacabana e Ipanema] a favor." (FUNDAÇÃO BIBLIOTECA NACIONAL, 2019k). 
Figura 3 - Foto da reportagem "Leblon e Lagoa pedem Escola Normal da ZS", do Diário Carioca de 24 de abril de 1959

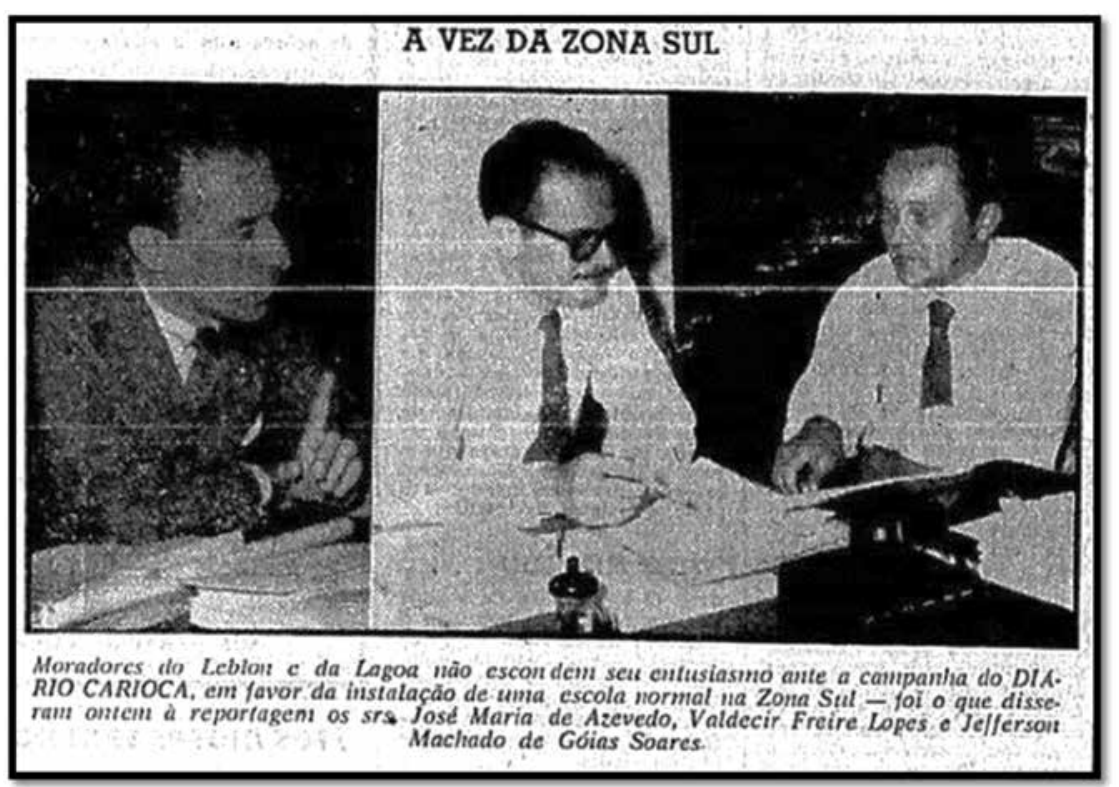

Fonte: Fundação Biblioteca Nacional (2019g).

Outras associações de Botafogo, Flamengo e Jardim Botânico também teriam se manifestado em campanha pela Escola Normal da Zona Sul. Algumas reportagens, além das fotos com o vereador Frederico Trotta, traziam imagens com o prefeito Sá Freire Alvim, o Secretário de Educação Jacobina Lacombe, sendo convocado até o ex-Presidente Eurico Gaspar Dutra, ressaltando-se que durante o seu mandato fora criada a ENCD. Em uma das reportagens, o Ministro do Tribunal de Contas Luiz Gama Filho foi procurado, pois seu nome, como fundador da universidade Gama Filho, no ano de 1939, poderia dar volume para a campanha. Em reportagem especial, o Ministro afirmou conhecer todo o processo de criação da nova unidade, envolvendo-se de maneira sentimental com o caso, afinal, segundo ele próprio afirmara, o vereador Frederico Trotta colocaria o nome de "Paulina Gama" na nova Escola Normal, em homenagem a sua mãe (FUNDAÇÃO BIBLIOTECA NACIONAL, 2019l).

Noutra ocasião, uma socialite carioca chegou a evocar a abertura de uma Escola Normal na região mais rica da cidade como nada mais do que um tratamento equitativo dado pela prefeitura, pois a zona norte já havia sido beneficiada.

\section{'SOCIETY' APLAUDE}

Considerada uma das principais damas da sociedade carioca, a sra. Heloísa (Helô) Amado, falando à reportagem, enalteceu a campanha 'uma escola normal para a Zona Sul', frisando que os bairros que a compõe crescem assustadoramente, sem que até hoje tenha resolvido o problema da educação normal para seus habitantes. 'O tratamento deve ser equitativo. Se já temos instaladas três escolas na Zona Norte, chegou a hora da outra parte da cidade ser beneficiada - Declarou Heloísa'. (FUNDAÇÃO BIBLIOTECA NACIONAL, 2019m).

De modo geral, as alegações levantadas buscavam ressaltar a falta de professores, além de apontar o entusiasmo e a participação da população no movimento. Entretanto, na falta de mais argumentos racionais, conforme já apontado anteriormente, era comum o Diário Carioca se utilizar de considerações não necessariamente precisas, como o sofrimento das jovens da Zona Sul em vir para o Centro da cidade ou para os subúrbios cariocas.

É triste ver o deslocamento de grande número de jovens para a Zona Norte, a fim de que possam, um dia, se tornar professoras. Perde-se hoje, nesta batalha do professorado, um grande contingente de moças de bom nível social por não concordarem seus pais que elas se dirijam a Madureira, Campo grande e Praça da Bandei- 
ra - onde funcionam as escolas normais - e isto devido à dificuldade de condução e outros obstáculos. [...] Por que a Zona Sul é tão desprotegida a ponto de não possuir uma só, enquanto a Zona Norte tem três? (FUNDAÇÃO BIBLIOTECA NACIONAL, 2019g).

Dias depois, ao entrevistar uma mãe, o Diário Carioca deu destaque:

[...] declarou a sra. Iluminata Portuni, residente em Copacabana $<<$ Se vitoriosa, prosseguiu, ela virá acabar com o sofrimento de milhares de mães que se veem obrigadas a viver separas de suas filhas durante quase todo o dia. Por acaso sabem as autoridades que uma normalista que cursa a Escola Normal Carmela Dutra, no período da manhã, precisa levantar-se às 5 horas para ali chegar às 8 ? E que com as aulas encerrandose às 12 horas, ela só poderá retornar ao lar às 15 horas? Que disposição para estudar terá a estudante depois dessa longa maratona? Como mãe, finalizou d. Iluminata, espero ver a vitória da campanha, que trará a tranquilidade a todas nós, possíveis mães e futuras normalistas >>. (FUNDAÇÃO BIBLIOTECA NACIONAL, 2019j).

Em outra ocasião, em tom ainda mais dramático, o jornal afirmou que encontrou apoio dentre as alunas do Instituto de Educação, envolvendo também a Escola Normal Sarah Kubitschek (ENSK) e a Escola Normal Carmela Dutra (ENCD), ao afirmar que "todos" apoiavam a ideia.

- Tenho uma amiguinha, acrescentou, que mora em Copacabana e que foi obrigada a matricularse em Campo Grande, na 'Sarah Kubitschek'.

- 0 sr. Já pensou, indagou ao repórter, quantos quilômetros vai andar essa criaturinha até chegar a se formar professora? Além de tomar duas conduções perigosíssimas, lotação e trem, é obrigada diariamente a fazer um percurso de ida e volta de 130 quilômetros. No fim do curso ela teria feito, sem dúvida, a volta ao mundo algumas vezes. A viagem é de 'matar'. Uma escola normal na Zona Sul resolveria o problema dela e de muitas outras.

\section{[...]}

- Seria tão bom se o Instituto pudesse ficar mais vazio...

Vera Lúcia mora no Catete, mas tem uma irmã que estuda na 'Carmela Dutra', em Madureira.

\section{$[\ldots]$}

- 'Tudo às avessas', suspirou. Afinal uma escola normal na Zona Sul acabaria em pouco tempo com o sacrifício de centenas de alunas. (FUNDAÇÃO BIBLIOTECA NACIONAL, 2019n).

Interessante considerar que as regiões fora dos centros urbanos recebem tradicionalmente no Distrito Federal uma classificação distinta do que originalmente se propõe para "subúrbio". Diferente do que é considerada uma região de descanso para as elites sociais ou demais classes que quisessem escapar do estilo de vida da cidade, como era em Roma, como é no caso dos Estados Unidos e em alguns países europeus, o "subúrbio carioca" recebeu uma conceituação ligada ao estrato social que habita a localidade. Essa parte da cidade foi - e ainda é - desenhada como desorganizada, com pouca estrutura de atendimento público, empobrecida, violenta e incivilizada (FERNANDES, 2011). 0 discurso adotado pelo periódico para atender a Zona Sul associava a pobreza ao perigo, classicamente, expondo um conceito que ficou conhecido como "classes perigosas", ${ }^{4}$ usado historicamente para processos de remoções de favelas, também identificadas como lócus de doenças de todo o tipo durante o século XX (MATTOS, 2009).

A srt. Talita Franco, estudante de medicina, em declarações ao DC, afirmou: '[...] Achamos formidável a campanha, pois ela resolverá, além de outros problemas, os choques que se produzem entre alunas da Zona Sul, em número inferior, com as da Zona Norte, numa escola nesta última localizada.' Estas foram as palavras das estudantes o Colégio Andrews, srtas. Marta Pacheco Marques e Sônia Regina Guimarães. Para a primeira, a iniciativa deste jornal alegrou extremamente, pois sua irmã, que em breve irá cursar a Escola Normal, não precisará deslocar-se para a Zona Norte, a fim de realizar sua vocação. (FUNDAÇÃO BIBLIOTECA NACIONAL, 2019j).

4 O conceito surgiu no Brasil no século XIX. Para o Historiador Rômulo Mattos, o cerne dessa conceituação é a indistinção entre pobreza e banditismo. "Os pobres carregavam vícios, os vícios produzem os malfeitores, os malfeitores são perigosos à sociedade; juntando os extremos da cadeia, temos a noção de que os pobres são, por definição, perigosos" (MATTOS, 2009, p. 166). 
O ponto alto da campanha para a unidade da Zona Sul, entretanto, foi a promoção feita pelo Diário Carioca de um debate ocorrido na TV-Rio, em que o "Prefeito Sá Freire Alvim, o secretário da Educação e Cultura da Municipalidade, prof. Américo Jacobina Lacombe, o vereador Frederico Trotta e um representante do DIÁRIO CARIOCA" (FUNDAÇÃO BIBLIOTECA NACIONAL, 2019o) realizaram debates sobre a Escola Normal da ZS no horário considerado nobre, isto é, às dezenove horas e vinte e cinco minutos.

Realizado o debate, e sob o consenso de que as jovens da Zona Sul sofriam demais com o deslocamento, foi noticiado no dia 13 de junho de 1959: "Prefeito dará em 60 Escola Normal da ZS [...] CONSUMADO” (FUNDAÇÃO BIBLIOTECA NACIONAL, 2019p).

\section{VITÓRIA}

A campanha visando instalar uma escola normal na Zona Sul (a fim de que as moças ali residentes, e que desejavam ser professoras, não sejam mais obrigadas a um longo percurso, diariamente, para estudar em estabelecimento idêntico na Zona Norte), foi objeto, este ano, de intensa campanha promovida por este jornal - campanha essa que culminou com um programa na TV-Rio, onde o prefeito Sá-Freire Alvim e o Sr. Jacobina Lacombe empenharam sua palavra de que dariam cumprimento à lei 906-57, do vereador Frederico Trotta, sancionada naquele ano, mas com sua execução protelada inexplicavelmente. (FUNDAÇÃO BIBLIOTECA NACIONAL, 2019q).

Com o argumento de que as jovens da Zona Sul não seriam mais obrigadas a seguir longas viagens em direção à Zona Norte, a Escola Normal da Zona Sul fora criada para atender um público diferenciado das suas congêneres suburbanas de Madureira, de Campo Grande e da Penha. Afinal, conforme já analisamos, o curso de formação de professores normalistas, para além da função precípua da instituição de formar e conformar profissionais para atuar nas redes de ensino particular e pública, também oferecia uma gama de outras possibilidades para as jovens que optavam pelo curso normal.

As transformações operadas no País determinaram mudança no status social da mulher, ampliando as suas reivindicações no campo da instrução. A Escola Normal foi o curso que parece ter satisfeito mais as aspirações educacionais das jovens brasileiras, oriundas não apenas das classes médias inferiores e superiores, mas também das famílias mais abastadas. Tanto assim, instalarem-se cursos normais nos colégios mais tradicionais, frequentados por moças das famílias mais ricas. (WEREBE, 1968, p. 216).

\section{A instalação da unidade e 0 atendimento exclusivo às elites}

Em abril de 1959, as autoridades e os jornais falavam da instalação da Escola Normal da Zona Sul na Praia Vermelha, bairro da Urca, onde também fica o principal campus e sede da reitoria da Universidade Federal do Rio de Janeiro (UFRJ), antes do início das atividades acadêmicas do campus do Fundão, na Ilha do Governador, nos anos 1970. Outra proposta apontava para um terreno na Gávea ou, ainda, um terreno na Praça do Lido, em Copacabana (FUNDAÇÃO BIBLIOTECA NACIONAL, 2019r). Comentou-se, também, sobre a instalação na Rua Prudente de Morais, em Ipanema (FUNDAÇÃO BIBLIOTECA NACIONAL, 2019s). Contudo, a professora primária Olga Dias (FUNDAÇÃO BIBLIOTECA NACIONAL, 2019t), escolhida para proceder nos estudos para a instalação da escola, apenas quinze dias depois de sua nomeação escolheu um prédio que considerou especial, na Lagoa Rodrigo de Freitas.

Embora já tenhamos apontado a região da Zona Sul como mais bem estruturada e onde se encontram os bairros com metro quadrado mais caros da cidade ainda nos dias de hoje, a construção da unidade atendeu a critérios de celeridade graças a uma pressão dos grupos que buscavam seu atendimento (LIMA, 2017). Olga Dias, nesse sentido, afirmou publicamente que apesar de o prédio ser pequeno e possuir rachaduras, receberia as reformas necessárias para receber o Curso Normal. Segundo o jornal Diário Carioca, que continuava a cobrir o passo-a-passo do evento, Olga receava apenas ter que remover os alunos da escola primária que já funcionava no local. Tal preocupação, 
no entanto, pareceu não se estender à Escola de Aplicação da Faculdade de Filosofia (FUNDAÇÃO BIBLIOTECA NACIONAL, 2019u), que também dividia o uso do prédio. Dessa forma, a unidade foi instalada provisoriamente em um prédio de educação primária, onde funcionava a Escola Pública Ignácio Manuel Azevedo do Amaral, na Rua Batista da Costa, no 55, Lagoa.

Ao apontar que "o curso normal da Zona Sul abrigará as moças daquela parte da cidade, estando as inscrições previstas para janeiro daquele ano, conforme manda a lei" (FUNDAÇÃO BIBLIOTECA NACIONAL, 2019u), o jornal também trouxe à tona a vitória dos Educadores da Escola Nova, quanto ao processo de descentralização dos sistemas de ensino, pois o Secretário de Educação Américo Jacobina Lacombe fez questão de confirmar a autonomia da unidade frente ao Instituto de Educação: “O texto legal não fala em anexo e sim em Escola Normal, nos moldes, portanto, da 'Carmela Dutra' ou da 'Sarah Kubitschek'” (FUNDAÇÃO BIBLIOTECA NACIONAL, 2019n).

Há ainda um outro bom argumento para ressaltar que a construção da Escola Normal da Zona Sul visava o atendimento exclusivo das jovens da sua região. Em um tempo em que o Túnel Rebouças ainda não tinha sido construído ${ }^{5}$ e o acesso entre as duas regiões era difícil e demorado, instalar uma unidade longe das linhas férreas mostrava a intenção de isolar a escola.

Segundo a geógrafa Therezinha Soares, a relação entre o subúrbio no Rio de Janeiro e o uso dos trens é tão profunda que, nos anos 1960, essa autora chegou a apontar que não eram chamados de subúrbios os bairros que não tivessem estações de trens. Soares também apontou, em conformidade com o que também já escrevemos, que o conceito carioca de "subúrbio" se concentra na relação entre o espacial e o social, e que essa ideia nada mais era do que uma maneira ideológica de dominação daqueles que moravam na Zona Sul (SOARES, 1962 apud FERNANDES, 2011). Assim, ao contrário das outras cinco unidades, ${ }^{6}$ a Escola Normal da Zona Sul, cercada pela cadeia de elevações conhecida como Maciço da Tijuca por um lado, também ficou distante do tradicional e histórico meio de transporte suburbano do Rio de Janeiro.

Figura 4 - Localização das Escolas Normais no Rio de Janeiro

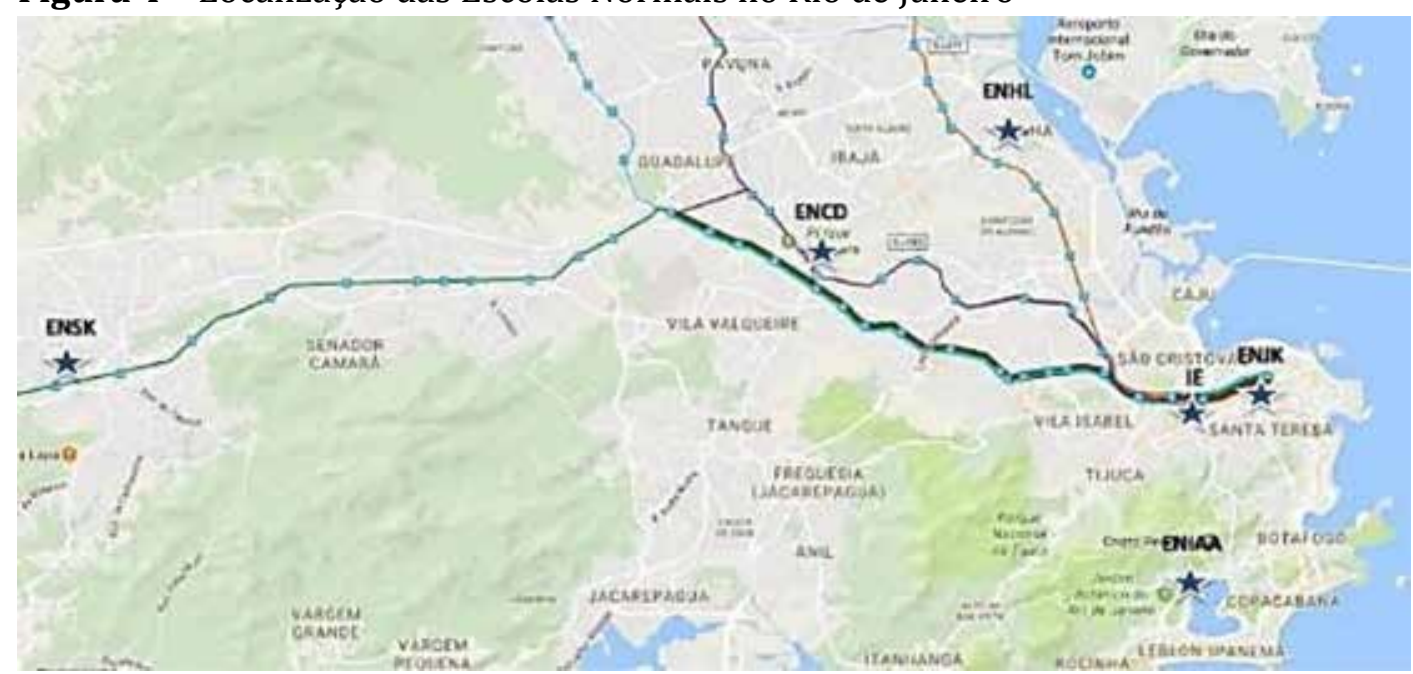

Fonte: Elaborado pelo autor deste artigo com base em Google Maps (2017).

5 O túnel Rebouças, nomeado em homenagem aos irmãos e engenheiros negros André Rebouças e Antônio Rebouças, foi inaugurado em 1967.

6 O Instituto de Educação, no bairro da Praça da Bandeira. A Escola Normal Júlia Kubitschek, no Centro da cidade. A Escola Normal Heitor Lira, no bairro da Penha. A Escola Normal Carmela Dutra, no bairro de Madureira e a Escola Normal Sara Kubitschek, no bairro de Campo grande. 
Por ocasião do anúncio de inauguração da unidade, o Secretário de Educação Américo Lacombe afirmou estar homenageando o antigo Reitor da Universidade do Brasil e Diretor da Escola Normal do Distrito Federal, adotando o mesmo nome da unidade primária que já ocupava o prédio, criando-se assim, a Escola Normal Ignácio Azevedo do Amaral (ENIAA) (FUNDAÇÃO BIBLIOTECA NACIONAL, 2019q).

Ignácio Manuel Azevedo do Amaral nasceu em 13 de abril de 1883, sendo filho do engenheiro ferroviário Ângelo Tomas do Amaral e de Maria Francisca Álvares de Azevedo do Amaral (1883-1950). Seu irmão mais velho, Antônio Azevedo do Amaral, foi considerado um dos expoentes do pensamento autoritário no início do século XX, defendendo um Estado intervencionista na economia, embora se opusesse firmemente ao pensamento fascista que se desenvolvia na Europa naquele período. Ignácio Azevedo do Amaral estudou na Escola Naval, onde se formou como oficial da Marinha e exerceu funções de instrução militar. Entre 1912 e 1914 foi livre-docente da cadeira de Geometria e Cálculo Infinitesimal na Escola Politécnica do Rio de Janeiro e depois tornouse professor do Colégio Pedro II, até que se reformou como Capitão-tenente. Em 1916 tornou-se docente da Escola Normal do Distrito Federal, assumindo no ano seguinte o posto de Diretor até 1920 (FUNDAÇÃO GETÚlIO VARGAS, 2017b).

Azevedo do Amaral voltou à Escola Naval em 1922 como catedrático da disciplina que lecionava. Em 1926 fez o mesmo em relação ao seu retorno à Escola Politécnica, tornando-se catedrático pela disciplina que anteriormente lecionou na unidade. Nos anos seguintes esteve na Escola de Marinha Mercante e no Instituto Técnico Naval em cargos de comando. Foi Diretor do Escritório do Plano da Universidade do Brasil a partir de 1935 e membro da comissão do plano dessa instituição depois de 1939. Integrou o Conselho Nacional de Educação de 1935 até 1937. Tornou-se reitor da Universidade do Brasil (futura UFRJ) entre os anos de 1945 e
1948 (FUNDAÇÃO GETÚLIO VARGAS, 2017b).

Por meio desse discurso que avaliamos, envolvendo interesses de ganhos políticos, de aumento da circulação do jornal para a zona norte da cidade e dos interesses de determinadas famílias cariocas, que em 17 de outubro de 1959, em troca de toda movimentação e promoção do nome do vereador Frederico Trotta e do prefeito Sá Freire Alvim, o Diário Carioca recebeu o título de "Benemérito do Rio", conforme notícia a seguir:

\section{DC ganhou título de 'Benemérito' do Rio}

A Câmara do Distrito Federal aprovou por unanimidade uma indicação do Vereador Frederico Trotta concedendo ao DIÁRIO CARIOCA, na pessoa de nosso diretor-presidente, jornalista Horário de Carvalho Júnior o título de 'Benemérito da Cidade do Rio de Janeiro'.

Motivou a distinção, a campanha vitoriosa, promovida em maio do corrente pelo DC, no sentido de ser instalada uma escola normal na Zona Sul, que embora criada pela lei 906/57, de autoria daquele vereador, tinha sua execução transferida inexplicavelmente de ano para ano. Foi igualmente ressaltada a atuação desse jornal em defesa dos interesses da população carioca, considerada em todos os bairros em que se concentra, notadamente na Zona Norte.

ESTÍMULO. Em cerimônia pública, a ser anunciada oportunamente, este jornal, através de seu redator -presidente, receberá das mãos do prefeito Sá Freire Alvim, no Palácio Guanabara, aquela distinção que a Câmara do Distrito Federal acaba de lhe outorgar. (FUNDAÇÃO BIBLIOTECA NACIONAL, 2019v).

\section{0 fim do interesse na formação de professores normalistas}

Coincidente com o período de mudança do Distrito Federal para Brasília e a elevação da cidade à condição de Estado da Guanabara, a primeira turma da ENIAA foi iniciada em 1960. Entretanto, três anos depois, um estudo realizado pelo Centro Brasileiro de Pesquisas Educacionais, ${ }^{7}$ coordenado pela professora Aparecida Joly Gouveia, já apresentou um perfil diferente da jovem que busca o Curso Normal no Brasil. Na pesquisa, foi feita uma pergunta

7 O Centro Brasileiro de Pesquisas Educacionais (CBPE) foi criado em dezembro de 1955, funcionando até 1964. 
simples e direta às jovens estudantes: "Por que preferiam a Escola Normal?" Como resultado, o estudo apresentou números que ainda estavam de acordo com o que Werebe (1968) e Louro (1997) já haviam apontado. Trinta e cinco por cento das jovens haviam escolhido o curso por conta da "Boa formação geral". Vinte e sete por cento escolheram como preparação para o casamento, enquanto $24 \%$ escolheram o curso por considerarem que as preparava bem para o magistério. A partir daí os números apontaram um desinteresse na profissão que tinha raiz nos baixos salários da classe. Dez por cento das alunas preferiam o curso como meio de acesso a outra profissão, $3 \%$ viam o diploma de normalistas como um meio de segurança econômica e 1\% atribuíam sua procura pelo curso à qualidade do meio social que encontrariam (FUNDAÇÃO BIBLIOTECA NACIONAL, 2019w).

A pesquisa fora estimulada por uma percepção de que o status e os salários dos pro- fessores primários estavam cada vez menos atrativos. Tornava-se cada vez mais fácil encontrar jornais cariocas que traziam manchetes como: "Problemas da normalista chegam com a formatura" (FUNDAÇÃO BIBLIOTECA NACIONAL, 2019w); "Ao Mestre, com sacrifício" (FUNDAÇÃO BIBLIOTECA NACIONAL, 2019x); "Grandeza e Decadência de uma profissão" (FUNDAÇÃO BIBLIOTECA NACIONAL, 2019y); "Professora perde encanto pela profissão que já lhe deu prestígio e bons salários" (FUNDAÇÃO BIBLIOTECA NACIONAL, 2019z).

Aquela normalista cuja trajetória de boa formação terminaria com um casamento perfeito com um cadete da Escola Militar nos anos 1940, então formada professora e atuante na rede municipal de ensino, apresentava a seguinte composição salarial inicial frente a um segundo tenente, cargo ocupado pelo cadete também já formado entre os anos 1960 e 1970 (Tabela 1).

Tabela 1 - Tabela Salário Mínimo Nacional/ Salário da Prof. Primária (Normalista) da GB/ Soldo do 2o Tenente do Exército

\begin{tabular}{ccccccc}
\hline Ano & $\$$ & $\begin{array}{c}\text { Sal. Mínimo } \\
\text { Nacional (SMN) }\end{array}$ & $\begin{array}{c}\text { Salário da Professora } \\
\text { Normalista }\end{array}$ & $\begin{array}{c}\text { Relação } \\
\text { Prof./SMN }\end{array}$ & $\begin{array}{c}\text { Soldo } \\
2^{\circ} \begin{array}{c}\text { Tenente } \\
\text { Exército }\end{array}\end{array}$ & $\begin{array}{c}\text { Relação } \\
2^{\circ} \text { Ten./SMN }\end{array}$ \\
\hline 1967 & NCr\$ & 105,00 & 195,00 & 1,86 & 229,50 & 2,18 \\
\hline 1968 & NCr\$ & 129,60 & 265,00 & 2,04 & 275,40 & 2,12 \\
\hline 1969 & NCr\$ & 156,00 & 265,00 & 1,70 & 660,96 & 4,23 \\
\hline 1970 & NCr\$ & 187,00 & 365,20 & 1,95 & 912,30 & 4,93 \\
\hline 1971 & Cr\$ & 225,60 & 380,00 & 1,68 & $1.095,00$ & 4,85 \\
\hline 1972 & Cr\$ & 268,80 & 525,88 & 1,95 & $1.578,00$ & 5,87 \\
\hline 1973 & Cr\$ & 312,00 & 555,00 & 1,83 & $1.815,00$ & 5,81 \\
\hline
\end{tabular}

Fonte: Elaborada pelo autor deste artigo com base em Lima (2017).

Estarrecimento maior causou a revista 0 Cruzeiro, que havia representado a normalista no final dos anos 1940 como uma espécie de jovem socialite a frequentar um curso de elite, e no final de 1960 apresentava um perfil bem diferente da normalista carioca. Ao colocar na capa da sua edição de setembro de 1969 uma jovem com broche da Escola Normal Ignácio Azevedo do Amaral, apresentou de forma direta o questionamento que muitas famílias já faziam sobre a formação naquela unidade: "Ser ou não ser professora [?]" 
Figura 5 - Capa da revista O Cruzeiro de 14 de setembro de 1968

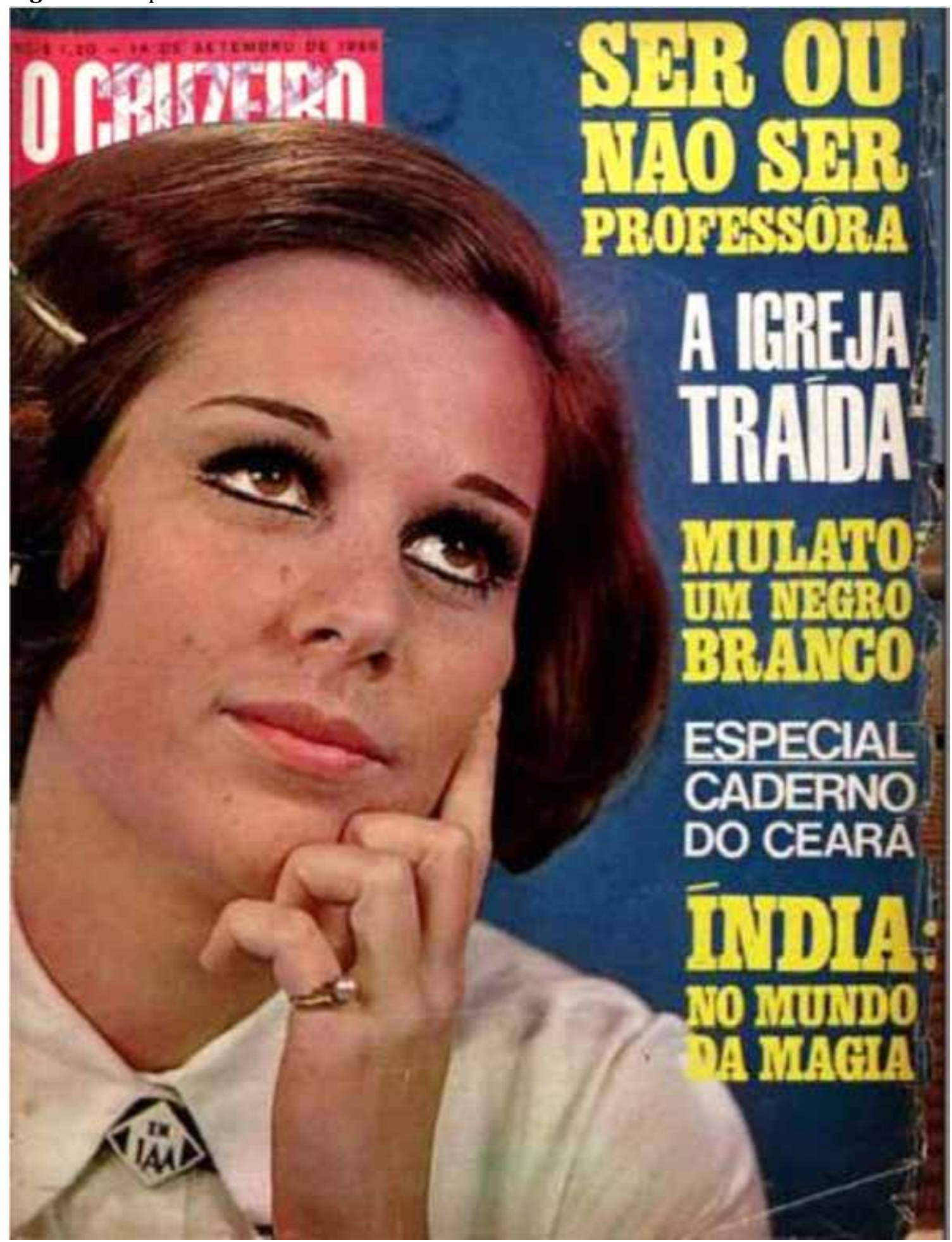

Fonte: Fundação Biblioteca Nacional (2019aa).

Seguida da pergunta no corpo de sua reportagem "Vale a pena ser professora no Brasil?", 0 Cruzeiro ainda trazia como reflexão o caso da professora normalista Maria Álvares Campos, formada no Instituto de Educação e empregada como frentista em um posto de combustível. A reportagem aponta não apenas o baixo salário, mas também a desconstrução do status social da profissão de professor nos anos 1960 e 1970 (FUNDAÇÃO BIBLIOTECA NACIONAL, 2019aa). 
Figura 6 - Foto interna da revista 0 Cruzeiro mostrando professora normalista trabalhando como frentista

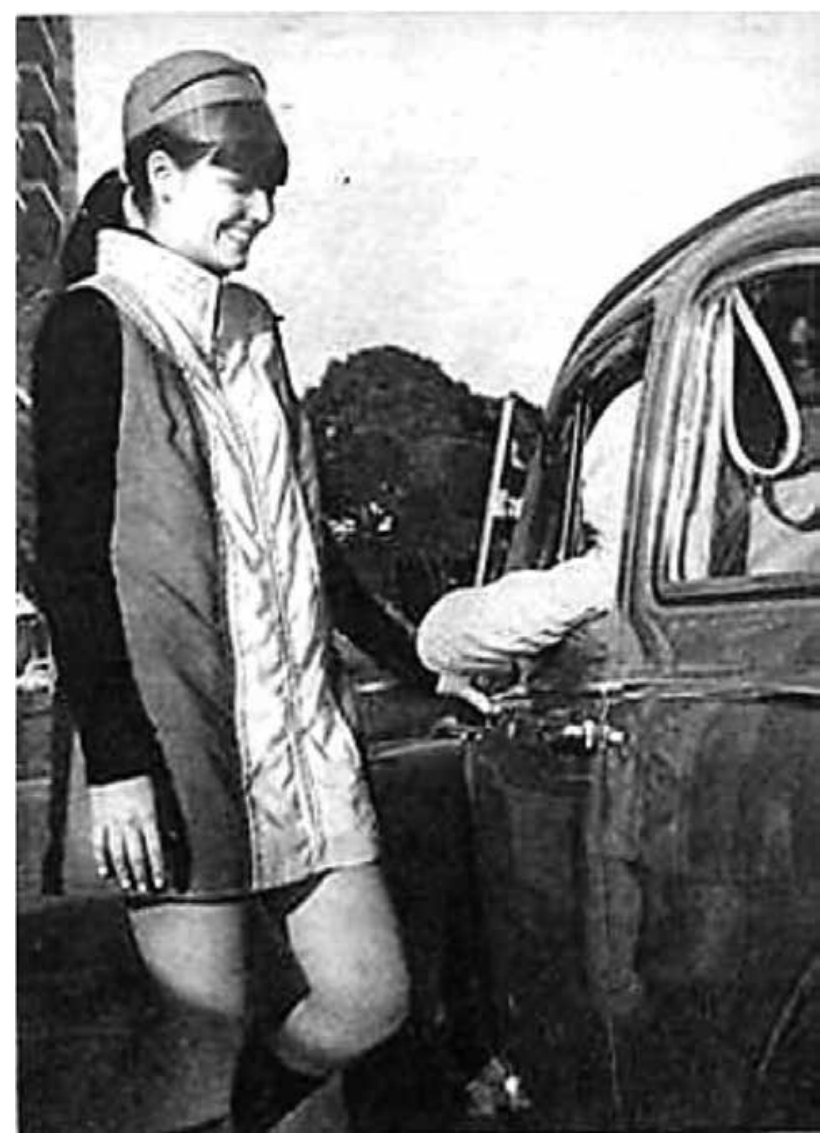

Fonte: Fundação Biblioteca Nacional (2019aa).

Rio, sete da manhã. Dona Maria Álvares Campos, de mini-saia amarela, calça as botas vermelhas e cano longo, dá os últimos retoques nos cabelos e no batom, e põe o anel de professora, que ganhou do pai ao diplomar-se no Instituto de Educação. Beija a mãe, que levantou cedo para servir-lhe o café, e sai para o trabalho - de recepcionista num posto de gasolina. [...] Maria Alvares Campos tinha doze anos quando terminou, no Rio, o curso de admissão. Filha de funcionário público, logo sentiu que não poderia continuar os estudos, a menos que fizesse o ginásio por conta do Governo. [...] Decidido que Maria Alvares Campo iria para a Escola Normal, ela, durante um ano inteiro, frequentou um cursinho preparatório para o exame de admissão, com aulas aos sábados, domingos, feriados e até mesmo no Natal. E, em janeiro, com outras dez mil, concorreu a uma das duas mil vagas abertas fazendo um exame quase que de adivinhação.

Aprovada e classificada, matriculou-se no primeiro ano do 1o ciclo, que corresponde ao ginásio. A família dá uma festa, para, mais uma vez, tomar a decisão. [...] Aos 18 anos, a última série.
Sonha com o vestido e baile, os convites para a formatura, a valsa com o namorado firme, e até mesmo com o salário e NCr\$130,00 [Professora Primária Estagiária] mensais que o Estado lhe dará para ir diariamente à para ir diariamente à zona rural lecionar durante quatro horas e voltar para casa, onde corrigirá provas e trabalhos durante outras quatro e dedicará mais duas à preparação da aula no dia seguinte.

0 professor, quanto aceita trabalhar nas zonas rurais, como fase de provação, ambiciona chegar aos centros maiores, fazendo com que os pedidos de remoção atinjam proporções impressionantes. [...] 0 êxodo dos professores formados e a ascensão dos leigos se devem, principalmente, ao fato de ser a remuneração do magistério insignificante, levando a profissão a um status social baixo.

\section{$[\ldots]$}

É exatamente aí, no último ano do curso, que Maria Álvares Campos descobre a realidade: que, para dar formação a uma criança, terá que morrer de fome, pedir carona, tirar do pai o pouco que ele não tem. Por demagogia ou real necessidade, o Estado decide ampliar o número de matrículas. Faltam professoras. E as alunas do último ano do Curso Normal são chamadas a lecionar - 'Para que estejam bem preparadas'. [...] Em fevereiro do ano seguinte, chamam-na para 'escolher' a escola. Em março, mandam-na para a que menos queria, e só em abril pagam-lhe o primeiro salário - em níveis do ano anterior. E Maria Álvares Campos, com o dinheiro, compra um jornal, lê um anúncio e começa a trabalhar como recepcionista do posto de gasolina em junho. (FUNDAÇÃO BIBLIOTECA NACIONAL, 2019aa).

Com a salário já mostrando ser insuficiente para o sustento da própria professora, o segundo impacto na carreira docente e no interesse das elites sobre o Curso Normal, conforme também aponta a reportagem, foi a perda do status social. No início dos anos 1970, tendo as liberdades civis submetidas pelo Ato Institucional $\mathrm{n}^{\circ}$ 5, de 13 de dezembro de 1968 (BRASIL, 1968), foi outorgada a Lei no 5.692, de 11 de agosto 1971 (BRASIL, 1971), obrigando toda formação de nível médio a se tornar ao menos uma habilitação técnica. Dessa maneira, o Curso Normal, ao lado de cursos como Auxiliar de 
Adubação, Classificador de Produtos Vegetais, Cadastrador de Agrimensura, Auxiliar Sanitarista, Auxiliar de Laboratório Têxtil em Fibras e Tecidos, Auxiliar de Escritório, Auxiliar de Contabilidade, Promotor de Vendas e muitas outras que na época tinham menor expressão social, se tornou mais um entre as cerca de 130 "habilitações" que o Conselho Federal de Educação (1972), no Parecer no 45/1972, autorizou o funcionamento no Brasil.

A Lei no 5.692/71 (BRASIL, 1971) tornou precária a formação educacional, informação quase que ponto pacífico entre os estudos acadêmicos, porém, outro ponto que nos interessa nela é a transformação das nomenclaturas de ensino primário, ginasial e médio. A Lei uniu o antigo curso Primário e Ginasial, formando o "1o Grau" de 8 anos seriados, além de transformar o ensino médio de 3 ou 4 anos em "2ํㅡㅁ. Grau". Nessa perspectiva, a formação de professores normalistas, de nível médio, fora relacionada na Lei como uma formação de $2^{\circ} \mathrm{Grau}$, de cunho profissionalizante. Para Leonor Tanuri (2000, p. 81), ao escrever sobre a história da formação de professores, após a publicação dessa Lei, houve:

[...] o 'esvaziamento', a 'desmontagem', a 'desestruturação', a 'perda de identidade' ou a 'descaracterização' sofrida pela escola normal no período, tendo-se vislumbrado inclusive sua 'desativação' nos anos imediatamente posteriores à reforma, devido à queda considerável da procura, ao fechamento de inúmeros cursos, paralelamente ao descaso de políticas nacionais e estaduais.

No Estado da Guanabara, uma legislação específica ainda aprofundou a descaracterização da identidade do Curso Normal, renomeando suas escolas como "Centros Interescolares", enfraquecendo uma longa tradição de identificação da qualidade de formação dessas escolas (GUANABARA, 1973). Dessa maneira, em 8 de novembro de 1974, quando, depois de 14 anos funcionando provisoriamente, a ENIAA foi transferida para uma sede definitiva na Rua Jardim Botânico, no 563, a apenas 200 metros de distância da sede anterior, embora a viúva de Azevedo do Amaral e o governador Chagas Freitas abrilhantassem o evento de inauguração, o nome da unidade já era Centro Interescolar Ignácio Azevedo do Amaral (LIMA, 2017).

Ao considerar as transformações na profissão docente, os historiadores Amarildo Ferreira Júnior e Marisa Bittar (2006) apontam um processo de proletarização da classe crescente entre os anos de 1964 e 1985, portanto, durante o período de ditadura militar. $\mathrm{Na}$ análise, intitulada $A$ ditadura militar e a proletarização dos professoras, os pesquisadores deram foco à condição socioeconômica dos docentes e à perda de status social desses profissionais. Para esses autores, segundo também defendemos, essas condições foram apresentadas como marcos de um processo de precarização da profissão docente. Contudo, acreditamos que o golpe mais forte nesse processo de precarização da profissão e na diminuição do interesse das elites na formação de professores normalistas foi dado mesmo em 1969.

Diante de um grande movimento de pressão de donos de escolas particulares de formação de professores e de famílias de alunos dessas escolas, o privilégio instituído no Império, sobrevivente à Proclamação da República, à Revolução de 1930 e aos Golpes de 1937 e de 1964, não conseguiu se sustentar. Os grupos que antes tinham liberdade de protestar e pressionar as autoridades para manter suas vantagens, por ocasião do AI-5 (BRASIL, 1968) e do Decreto-Lei no 477 (BRASIL, 1969), de 26 de fevereiro de 1969, que definiu infrações disciplinares praticadas por professores, alunos, funcionários ou empregados de estabelecimentos de ensino público ou particulares, não podiam ir às ruas para reivindicar a manutenção desse privilégio.

\section{ADVERTÊNCIA}

As alunas que cursam as últimas turmas de terceiro ano normal, já que à partir do ano passado o normal teve acrescentado mais um ano de aperfeiçoamento, vêm recebendo uma série de 
advertências por parte dos diretores de todas as escolas normais oficiais no sentido de que se abstenham de dar entrevistas à imprensa ou mesmo de participar de reuniões ou movimentos que reivindiquem o ingresso no magistério público primário sem a prestação de concurso público.

Os Círculos de Pais e Mestres das escolas normais do Estado estão distribuindo circulares em todas as turmas do normal 'aconselhando' suas alunas a não tomarem medidas precipitadas visando a conseguir aquela reivindicação. Prometeram ainda comunicar às alunas todos os movimentos de três advogados que foram contratados para livrar aquelas que se formam este ano, da prestação do concurso, conforme ficou estipulado depois que o STF considerou 'inconstitucional' o inciso 'b', do artigo 73 da Constituição do Estado da Guanabara, que garantia o direito de nomeação para o serviço público a todas àquelas que se formassem pelas escolas normais. (FUNDAÇÃO BIBLIOTECA NACIONAL, 2019ab).

Enquanto o caso ainda estava no Supremo Tribunal Federal, por meio do Decreto "E" 3.700, de 26 de janeiro de 1970 (FUNDAÇÃO BIBLIOTECA NACIONAL, 2019ac), foi anunciado que as formandas das Escolas Normais Públicas do ano de 1969 do Estado da Guanabara, contratadas ex-officio, permaneceriam nas escolas até o fim do ano de 1970, e que por volta desse mesmo período seria realizado o primeiro concurso público para o provimento de professores primários do Estado.
Art. 1o - A Secretaria de Administração promoverá, através da Escola de Serviço Público do Estado da Guanabara, no prazo de 30 dias, a abertura de concurso público para o provimento das vagas da classe de professor primário.

Art. 2 - A Secretaria de Educação e Cultura fica autorizada a contratar os professores formados pelas escolas normais oficiais do Estado, no ano de 1969, sob o regime da legislação trabalhista.

Parágrafo $1^{0}$ - Os professores contratados na forma deste artigo serão inscritos <<ex-officio>> no concurso público a que se refere o artigo primeiro.

Parágrafo $2^{\mathrm{o}}$ - Os contratos em conformidade com o presente decreto serão celebrados por prazo determinado e considerados extintos no término do corrente ano letivo de 1970. (FUNDAÇÃO BIBLIOTECA NACIONAL, 2019ad).

Diante desse quadro, um dos certames mais concorridos do antigo Distrito Federal e agora Estado da Guanabara apresentou uma queda nunca antes vista na procura em todas as unidades. Em 1969 foi preciso realizar três vezes o concurso para que as vagas fossem cobertas. Em 1970, enquanto a unidade suburbana de Madureira começava a se recuperar, o ENIAA chegou a ter menos candidatos do que vagas. A profissão de professor deixava, definitivamente, de contar com qualquer interesse das classes mais abastadas, mas continuaria como uma realização pessoal ou como um símbolo de crescimento social para as classes mais pobres da cidade.

Tabela 2 - Relação candidato/vaga da ENCD entre as décadas de 1960 e 1970

\begin{tabular}{|c|c|c|c|c|c|c|c|c|}
\hline \multicolumn{9}{|c|}{ ENCD } \\
\hline Condidatos totoic & $67 \quad 68$ & $69-1^{o}$ & $69-2^{\circ}$ & $69-3^{\circ}$ & 70 & 71 & 72 & 73 \\
\hline Candidatos totals & --- 2687 & 2407 & 1125 & 583 & 917 & 1687 & 1608 & --- \\
\hline vagas totals & --- 175 & 238 & 76 & 51 & 280 & 112 & 105 & --- \\
\hline Canumuato/vaga & --- 15,35 & 10,11 & 14,80 & 11,43 & 3,28 & 15,06 & 15,31 & --- \\
\hline
\end{tabular}

Fonte: Elaborada pelo autor deste artigo com base em Lima (2017).

Tabela 3 -Relação candidato/vaga da ENIAA entre as décadas de 1960 e 1970

\begin{tabular}{|c|c|c|c|c|c|c|c|c|}
\hline \multicolumn{9}{|c|}{ ENIAA } \\
\hline \multirow{4}{*}{$\begin{array}{l}\text { Candidatos totais } \\
\text { Vagas totais } \\
\text { Candidato/vaga }\end{array}$} & $67 \quad 68$ & $69-1$ & $69-2$ & $69-3^{o}$ & 70 & 71 & 72 & 73 \\
\hline & --- 351 & 256 & 411 & 55 & 196 & 111 & 140 & --- \\
\hline & --- 126 & 119 & 97 & 25 & 92 & 112 & 140 & --- \\
\hline & $---\quad 2,79$ & 2,15 & 4,24 & 2,20 & 2,13 & 0,99 & 1,00 & --- \\
\hline
\end{tabular}

Fonte: Elaborada pelo autor deste artigo com base em Lima (2017). 


\section{CONCLUSÃO}

De fato, a partir do que demonstramos, a formação de professores normalistas no início do século XX interessava às famílias de classe média e às elites sociais. Seja por motivos que envolviam a "boa formação das mulheres brasileiras" ou porque as famílias buscavam um bom casamento para as suas filhas, ou ainda porque seria possível um "seguro de vida" financeiro para essas jovens, o Curso Normal era um curso de referência na região que já foi a capital do Império, a capital da República, o estado da Guanabara e hoje é a cidade do Rio de Janeiro.

A procura por essa formação levou à criação da Escola Normal Ignácio Azevedo do Amaral na região mais rica da cidade na uma época em que o trânsito entre as Zonas Norte a Sul era de difícil acesso. A construção de uma unidade exclusiva para o atendimento das jovens serviu para esse fim por poucos anos, pois na década de 1960, mais notadamente após a ditadura civil-militar, a situação da normalista e do Curso Normal mudou drasticamente.

Em meados dos anos 1960, por efeito de políticas públicas nacionais que não se preocuparam em recuperar o salário dos professores, houve uma sensível perda salarial, levando as formandas das Escolas Normais a procurar um segundo emprego ou mesmo a abandonar a docência. A Lei no 5.692/71 (BRASIL, 1971), aliada às perdas salarias ano após ano, nivelou o Curso Normal a cursos que não tinham o mesmo prestígio social, acarretando uma perda de status social das normalistas. Por fim, a perda do privilégio de se tornar servidor público automaticamente após o final da formação, algo que se tornou característico das professoras normalistas, foi derrubado em 1969, ocasionando a diminuição da procura pelas Escolas Normais, principalmente a ENIAA. A conjunção desses fatores encerrou a procura de parte das elites que acreditavam que tal formação seria uma opção de crescimento social para suas filhas.

Por fim, vale deixar a reflexão e o aprendizado com o passado sobre a importância de políti- cas públicas que podem construir as condições necessárias para que a profissão docente não continue a constar no Brasil uma categoria de tão baixos salários. Relacionado a isso, acompanhamos atualmente uma degradação da confiança nos professores, refletindo a falta de respeito que vai desde os legisladores até as salas de aula do país. Retomar a importância da docência passa, portanto, pela revalorização da classe, o que pode passar, inclusive, como nas palavras de Ruy Barbosa, pelo estabelecimento de vantagens para esses trabalhadores.

\section{REFERÊNCIAS}

BRASIL. Decreto no 1.331-A, de 17 de fevereiro de 1854. Aprova o Regulamento para a reforma do ensino primário e secundário do Município da Corte. Disponível em: http://www2.camara.leg. br/legin/fed/decret/1824-1899/decreto-1331a-17-fevereiro-1854-590146-publicacaooriginal115292-pe.html. Acesso em: 21 set. 2017.

BRASIL. Decreto no 10.060 , de 13 de outubro de 1888. Dá novo Regulamento à Escola Normal. Coleção das Leis do Império do Brasil de1888 Parte II, Tomo LI - Vol. II. Rio de Janeiro: Tipografia Nacional, 1889. p. 343-381. Disponível em: http:// brazil.crl.edu/bsd/bsd/u1374/000207.html. Acesso em: 01 ago. 2016.

BRASIL. Presidência da República. Casa Civil. Ato Institucional no 5, de 13 de dezembro de 1968. São mantidas a Constituição de 24 de janeiro de 1967 e as Constituições Estaduais; O Presidente da República poderá decretar a intervenção nos estados e municípios, sem as limitações previstas na Constituição, suspender os direitos políticos de quaisquer cidadãos pelo prazo de 10 anos e cassar mandatos eletivos federais, estaduais e municipais, e dá outras providências. Brasília, DF, 1968. Disponível em: http://www.planalto.gov.br/ccivil_03/ait/ait05-68.htm. Acesso em: 06 jan. 2015.

BRASIL. Presidência da República. Casa Civil. Decreto-Lei no 477, de 26 de fevereiro de 1969. Define infrações disciplinares praticadas por professores, alunos, funcionários ou empregados de estabelecimentos de ensino público ou particulares, e dá outras providências. Brasília, DF, 1969. Disponível em: http://www.planalto.gov.br/ CCiViL_03/LEIS/L5692.htm. Acesso em: 29 ago. 2017. 
BRASIL. Presidência da República. Casa Civil. Lei no 5.692, de 11 de agosto de 1971. Fixa diretrizes e bases para o ensino de $1^{\circ}$ e $2^{\circ}$ graus, e dá outras providências. Brasília, DF, 1971. Disponível em: http://www.planalto.gov.br/CCiViL_03/DecretoLei/1965-1988/Del0477.htm. Acesso em: 29 ago. 2017.

BRASIL, Bruno. Biblioteca Nacional. Hemeroteca Digital. 0 Cruzeiro. 2015. Disponível em: https:// bndigital.bn.gov.br/artigos/o-cruzeiro/. Acesso em: 10 jan. 2020.

CANÁRIO, Rui. A escola: das "promessas" às "incertezas". Revista Unisinos, v. 12, n. 2, p. 7381, 2008.

CONSELHO FEDERAL DE EDUCAÇÃO. Parecer CFE no 45, de 12 de janeiro de 1972. A qualificação para o trabalho no ensino de 2. ${ }^{\circ}$ grau. 0 mínimo a ser exigido em cada habilitação profissional. Brasília, DF, 1972. Disponível em: siau.edunet. sp.gov.br/ItemLise/arquivos/notas/parcfe45_72. doc. Acesso em: 29 ago. 2017.

DISTRITO FEDERAL (RIO DE JANEIRO). Lei no 906, de 16 de dezembro de 1957. Determina a distribuição de lotes gratuitos aos favelados, soluciona o problema das favelas, e dá outras providências. Rio de Janeiro, 1957. Disponível em: https://www.jusbrasil.com.br/. Acesso em: 02 ago. 2016.

FERNANDES, Nelson da Nóbrega. 0 rapto ideológico da categoria subúrbio: Rio de Janeiro 18581945. Rio de Janeiro: Apicuri, 2011.

FERREIRA JÚNIOR, Amarilio; BITTAR, Marisa. A ditadura militar e a proletarização dos professores. Educação e Sociedade, Campinas, SP, v. 27, n. 97, p. 1159-1179, set./dez 2006.

FUNDAÇÃO BIBLIOTECA NACIONAL. Biblioteca Nacional Digital. Hemeroteca Digital. Periódicos. As normalistas do Rio de Janeiro - vestida de azul e branco. 0 Cruzeiro, 22 out. 19591949. Disponível em: https://bndigital.bn.gov.br/hemerotecadigital/. Acesso em: 12 fev. 2019a.

FUNDAÇÃO BIBLIOTECA NACIONAL. Biblioteca Nacional Digital. Hemeroteca Digital. Periódicos. Criação de Novas Escolas Normais. Diário de Notícias, 21 fev. 1957, p. 4. Disponível em: https:// bndigital.bn.gov.br/hemeroteca-digital/. Acesso em: 11 mar. 2019b.

FUNDAÇÃO BIBLIOTECA NACIONAL. Biblioteca Nacional Digital. Hemeroteca Digital. Periódicos. Técnicos contra a criação de Novas Escolas
Normais. A Noite, 30 nov. 1957, p. 7. Disponível em: https://bndigital.bn.gov.br/hemeroteca-digital/. Acesso em: 12 fev. 2019c.

FUNDAÇÃO BIBLIOTECA NACIONAL. Biblioteca Nacional Digital. Hemeroteca Digital. Periódicos. Criada ontem a Escola Normal de Campo Grande. Diário de Notícias, 28 nov. 1957, p. 2. Disponível em: https://bndigital.bn.gov.br/hemerotecadigital/. Acesso em: 5 fev. 2019d.

FUNDAÇÃO BIBLIOTECA NACIONAL. Biblioteca Nacional Digital. Hemeroteca Digital. Periódicos. População da Zona Sul pede Escola Normal. Diário Carioca, 20 abr. 1959, p. 1. Disponível em: https:// bndigital.bn.gov.br/hemeroteca-digital/. Acesso em: 22 abr. 2019 e.

FUNDAÇÃO BIBLIOTECA NACIONAL. Biblioteca Nacional Digital. Hemeroteca Digital. Periódicos. Literatos a favor da Escola Normal na ZS. Diário Carioca, 11 maio 1959, p. 1. Disponível em: https:// bndigital.bn.gov.br/hemeroteca-digital/. Acesso em: 15 fev. 2019 f.

FUNDAÇÃO BIBLIOTECA NACIONAL. Biblioteca Nacional Digital. Hemeroteca Digital. Periódicos. Leblon e Lagoa pedem Escola Normal na ZS. Diário Carioca, 24 abr. 1959, p. 1. Disponível em: https:// bndigital.bn.gov.br/hemeroteca-digital/. Acesso em: 07 fev. 2019g.

FUNDAÇÃO BIBLIOTECA NACIONAL. Biblioteca Nacional Digital. Hemeroteca Digital. Periódicos. Urca vai lutar por Escola Normal na ZS. Diário Carioca, 25 abr. 1959, p. 1. Disponível em: https:// bndigital.bn.gov.br/hemeroteca-digital/. Acesso em: 12 fev. 2019h.

FUNDAÇÃO BIBLIOTECA NACIONAL. Biblioteca Nacional Digital. Hemeroteca Digital. Periódicos. Escola Normal pode ser instalada logo. Diário Carioca, 27 maio 1959, p. 1. Disponível em: https:// bndigital.bn.gov.br/hemeroteca-digital/. Acesso em: 21 fev. 2019i.

FUNDAÇÃO BIBLIOTECA NACIONAL. Biblioteca Nacional Digital. Hemeroteca Digital. Periódicos. Moças de Copa apoiam Escola Normal na ZS. Diário Carioca, 27 abr. 1959, p. 1. Disponível em: https:// bndigital.bn.gov.br/hemeroteca-digital/. Acesso em: 16 abr. 2019j.

FUNDAÇÃO BIBLIOTECA NACIONAL. Biblioteca Nacional Digital. Hemeroteca Digital. Periódicos. PDF tem verba para Escola Normal na ZS. Diário Carioca, 30 abr. 1959, p. 1. Disponível em: https:// bndigital.bn.gov.br/hemeroteca-digital/. Acesso 
em: 23 fev. 2019k.

FUNDAÇ̃̃O BIBLIOTECA NACIONAL. Biblioteca Nacional Digital. Hemeroteca Digital. Periódicos. Escola já tem nome. Diário Carioca, 03 jun. 1959, p. 1. Disponível em: https://bndigital.bn.gov.br/ hemeroteca-digital/. Acesso em: 23 fev. 20191.

FUNDAÇÃO BIBLIOTECA NACIONAL. Biblioteca Nacional Digital. Hemeroteca Digital. Periódicos. Dutra ao DC: "escola merece meu aplauso". Diário Carioca, 22 abr. 1959, p. 1. Disponível em: https:// bndigital.bn.gov.br/hemeroteca-digital/. Acesso em: 22 fev. 2019m.

FUNDAÇÃO BIBLIOTECA NACIONAL. Biblioteca Nacional Digital. Hemeroteca Digital. Periódicos. Grêmio 'Rui.... Diário Carioca, 30 maio 1959, p. 11. Disponível em: https://bndigital.bn.gov.br/ hemeroteca-digital/. Acesso em: 28 fev. 2019n.

FUNDAÇÃO BIBLIOTECA NACIONAL. Biblioteca Nacional Digital. Hemeroteca Digital. Periódicos. Campanha pró-escola levada à TV. Diário Carioca, 05 maio 1959, p. 1. Disponível em: https:// bndigital.bn.gov.br/hemeroteca-digital/. Acesso em: 24 fev. 2019 o.

FUNDAÇÃO BIBLIOTECA NACIONAL. Biblioteca Nacional Digital. Hemeroteca Digital. Periódicos. Prefeito dará em 60 Escola Normal da ZS. Diário Carioca, 13 jun. 1959, p. 3. Disponível em: https:// bndigital.bn.gov.br/hemeroteca-digital/. Acesso em: 12 fev. 2019p.

FUNDAÇÃO BIBLIOTECA NACIONAL. Biblioteca Nacional Digital. Hemeroteca Digital. Periódicos. Zona Sul ganhou uma Escola Normal: Lagoa. Diário Carioca, 16 out. 1959, p. 1. Disponível em: https:// bndigital.bn.gov.br/hemeroteca-digital/. Acesso em: 26 de mar. de 2019q.

FUNDAÇÃO BIBLIOTECA NACIONAL. Biblioteca Nacional Digital. Hemeroteca Digital. Periódicos. Jacobina se... Diário Carioca, 19 abr. 1959, p. 3. Disponível em: https://bndigital.bn.gov.br/ hemeroteca-digital/. Acesso em: 18 mar. 2019r.

FUNDAÇÃO BIBLIOTECA NACIONAL. Biblioteca Nacional Digital. Hemeroteca Digital. Periódicos. Escola Normal até o fim do ano: Prefeito. Diário Carioca, 21 abr. 1959, p. 1. Disponível em: https:// bndigital.bn.gov.br/hemeroteca-digital/. Acesso em: 15 abr. 2019s.

FUNDAÇÃO BIBLIOTECA NACIONAL. Biblioteca Nacional Digital. Hemeroteca Digital. Periódicos. Escola Normal na ZS. Diário Carioca, 14 ago. 1959, p. 1. Disponível em: https://bndigital.bn.gov.br/ hemeroteca-digital/. Acesso em: 10 maio 2019t.

FUNDAÇÃO BIBLIOTECA NACIONAL. Biblioteca Nacional Digital. Hemeroteca Digital. Periódicos. Prédio na Lagoa para a Escola Normal na ZS. Diário Carioca, 29 ago. 1959, p. 1. Disponível em: https:// bndigital.bn.gov.br/hemeroteca-digital/. Acesso em: 13 fev. $2019 \mathrm{u}$

FUNDAÇÃO BIBLIOTECA NACIONAL. Biblioteca Nacional Digital. Hemeroteca Digital. Periódicos. DC ganhou título de "Benemérito" do Rio. Diário Carioca, 17 out. 1959, p. 1. Disponível em: https:// bndigital.bn.gov.br/hemeroteca-digital/. Acesso em: 12 abr. 2019v.

FUNDAÇÃO BIBLIOTECA NACIONAL. Biblioteca Nacional Digital. Hemeroteca Digital. Periódicos. Brasil forma mestras que não ensinam. Tribuna de Imprensa, 24 out. 1963, p. 12. Disponível em: https://bndigital.bn.gov.br/hemeroteca-digital/. Acesso em: 7 abr. 2019x.

FUNDAÇÃO BIBLIOTECA NACIONAL. Biblioteca Nacional Digital. Hemeroteca Digital. Periódicos. Grandeza e decadência de uma profissão. Jornal do Brasil, 15 dez. 1967, p. 1. Disponível em: https:// bndigital.bn.gov.br/hemeroteca-digital/. Acesso em: 12 fev. 2019y.

FUNDAÇÃO BIBLIOTECA NACIONAL. Biblioteca Nacional Digital. Hemeroteca Digital. Periódicos. Ao mestre, com sacrifício. Correio da Manhã, 16 out. 1962, p. 4. Disponível em: https:/ /bndigital.bn.gov. br/hemeroteca-digital/. Acesso em: 15 abr. 2019w.

FUNDAÇÃO BIBLIOTECA NACIONAL. Biblioteca Nacional Digital. Hemeroteca Digital. Periódicos. Professora perde encanto pela profissão que já lhe deu prestígio e bons salários. Jornal do Brasil, 04 fev. 1973, p. 3. Disponível em: https://bndigital. bn.gov.br/hemeroteca-digital/. Acesso em: 22 fev. 2019z.

FUNDAÇÃO BIBLIOTECA NACIONAL. Biblioteca Nacional Digital. Hemeroteca Digital. Periódicos. O Cruzeiro, 14 set. 1968. Disponível em: https:// bndigital.bn.gov.br/hemeroteca-digital/. Acesso em: 19 mar. 2019aa.

FUNDAÇÃO BIBLIOTECA NACIONAL. Biblioteca Nacional Digital. Hemeroteca Digital. Periódicos. Normalistas não podem defender seu movimento. Tribuna da Imprensa, 24 mar. 1969, p. 2. Disponível em: https://bndigital.bn.gov.br/ hemeroteca-digital/. Acesso em: 12 mar. 2019ab.

FUNDAÇÃO BIBLIOTECA NACIONAL. Biblioteca Nacional Digital. Hemeroteca Digital. Periódicos. 
Professores primários são chamados a escolher escola. Diário de Notícias, 21 fev. 1970, p. 9. Disponível em: https://bndigital.bn.gov.br/ hemeroteca-digital/. Acesso em: 24 maio 2019ac.

FUNDAÇÃO BIBLIOTECA NACIONAL. Biblioteca Nacional Digital. Hemeroteca Digital. Periódicos. Ensino primário: Concurso. Diário de Notícias, 28 jan. 1970, p. 2. Disponível em: https://bndigital. bn.gov.br/hemeroteca-digital/. Acesso em: 24 abr. 2019ad.

FUNDAÇÃO GETÚLIO VARGAS (FGV). CPDOC. Diário Carioca. Disponível em: http://cpdoc.fgv.br/ sites/default/files/verbetes/primeira-republica/ DI\%C3\%81RIO\%20CARIOCA.pdf. Acesso em: 08 fev. 2017a.

FUNDAÇÃO GETÚLIO VARGAS (FGV). CPDOC. Azevedo do Amaral. Disponível em: http://www.fgv. br/cpdoc/acervo/dicionarios/verbete-biografico/ amaral-azevedo-do. Acesso em: 08 fev. 2017b.

GOOGLE MAPS. Escolas Normais do Rio de Janeiro. Disponível em: https://www.google.com.br/ maps. Acesso dia: 01 de jun. 2017.

GUANABARA. Acervo do Colégio Estadual Heitor Lira. Decreto Estadual “E” no 6.071, de 1973. Rio de Janeiro, 1973. Consultado no dia 20 de set. 2017.

INSTITUTO BRASILEIRO DE GEOGRAFIA E ESTATÍSTICA (IBGE). Censo Demográfico 1940/2010. Disponível em: http:// seriesestatisticas.ibge.gov.br/. Acesso em: 19 jan. 2019.

LEITE RIBEIRO. Explanação sobre a criação do uniforme para a Escola Normal. O PAIZ, Rio de Janeiro, 11 dez. 1914. Conselho Municipal. Expediente. p. 7.

LIMA, Fábio Souza. A história por trás da origem do uniforme azul e branco das normalistas do Rio de Janeiro. Revistaleph, n. 31. p. 1-30, 2018.

LIMA, Fábio Souza. As normalistas chegam ao subúrbio - a história da Escola Normal Carmela Dutra: da criação à autonomia administrativa (1946-1953). 1. ed. São Paulo: All Print, 2016.

LIMA, Fábio Souza. As normalistas do Rio de Janeiro - o ensino normal público carioca (1920-1970): das tensões políticas na criação das instituições à produção das diferentes identidades de suas alunas. 20017. 383 f. Tese (Doutorado em Educação) - Universidade Federal do Rio de Janeiro (UFRJ), Rio de Janeiro, 2017.

LOPES, Sonia de Castro. Políticas de formação de professores nos anos 1950: problematizando os "anos dourados" do Instituto de Educação do Rio de Janeiro. Revista Cadernos de História da Educação. v. 12, n. 1, jan./jun. 2013.

LOPES, Sonia de Castro. Um ensaio de formação docente no Rio de Janeiro: a Escola Normal Livre do Município da Corte (1874-1875). História da Educação, Pelotas, RS, v. 16, p. 134-155, 2012.

LOURO, Guacira. Mulheres na sala de aula. In: PRIORE, Mary del (org.). História das mulheres no Brasil. São Paulo: Contexto, 1997. p. 443-481.

LUCA, Tania Regina de. História dos, nos e por meio dos periódicos. In: PINSKY, C. B. (org.). Fontes Históricas. São Paulo, Contexto, 2005. p. 111-153.

LUCA, Tania Regina de. Revista do Brasil (19381943), um projeto alternativo? In: DUTRA, Eliana F.; MOLLIER, Jean-Yves (org.). Política, nação e edição: o lugar dos impressos na construção da vida política. Brasil, Europa e Américas nos séculos XVIII-XX. São Paulo: Annablume, 2006. p. 315-335.

MATTOS, Romulo Costa. As "classes perigosas" habitam as favelas: um passeio pela crônica policial no período das reformas urbanas. Desigualdade e Diversidade, Rio de Janeiro, n. 5, p. 149-170, jul./ dez. 2009.

MEDEIROS, Benício. Nunca houve um jornal como ele. In: COSTA, Cecília (org.). Diário Carioca - 0 jornal que mudou a imprensa brasileira. Rio de Janeiro: Biblioteca Nacional, 2011. p. 9-15 (Cadernos da Biblioteca Nacional, 9).

PRIORI, Ângelo. Et al. História do Paraná: séculos XIX e XX. Maringá, PR: Editora da Universidade Estadual de Maringá (UEM), 2012.

PINTO, José Marcelino; BRANT, Liliane Lúcia; SAMPAIO, Carlos Eduardo. Um olhar sobre os indicadores de analfabetismo no Brasil. Revista Brasileira de Estudos Pedagógicos, Brasília, DF, v. 81, n. 199, p. 511-524, set./dez. 2000.

RÉMOND, René. Por uma história política. Rio de Janeiro: Editora da FGV, 2003.

SILVEIRA, João Batista da. A política de formação de professores de história no Regime Civil-Militar: a criação da Licenciatura Curta em Estudos Sociais. 2008. Dissertação (Mestrado em Educação) - Pontifícia Universidade Católica de São Paulo (PUC-SP), Campinas, SP, 2008.

TANURI, Leonor Maria. História da formação de professores. Revista Brasileira de Educação, n. 14, p. 61-88, 2000. 
TROTTA, Carolina. Frederico Trotta. Blog de Carolina Trotta. Porto Velho, 17 ago. 2012. Disponível em http://frederico-trotta.blogspot.com.br/. Acessado em: 18 maio 2017.

VILLELA, Heloísa. A primeira escola normal do Brasil - uma contribuição à história da formação de professores. 1990. Dissertação (Mestrado em Educação) - Universidade Federal Fluminense (UFF), Rio de Janeiro, 1990.

WEREBE, Maria José Garcia. Grandezas e misérias do ensino no Brasil. São Paulo, Difusão Europeia do Livro, 1968.

WEST, Ladyce. Meus tiranos, poema de Frederico Trotta, em homenagem ao dia dos avó. Peregrina cultural. Rio de Janeiro, 26 jul. 2011. Disponível em: https://peregrinacultural.wordpress.com/. Acessado dia 18 de mai. de 2017.

Recebido em: 20/01/2020

Aprovado em: 27/08/2020 